
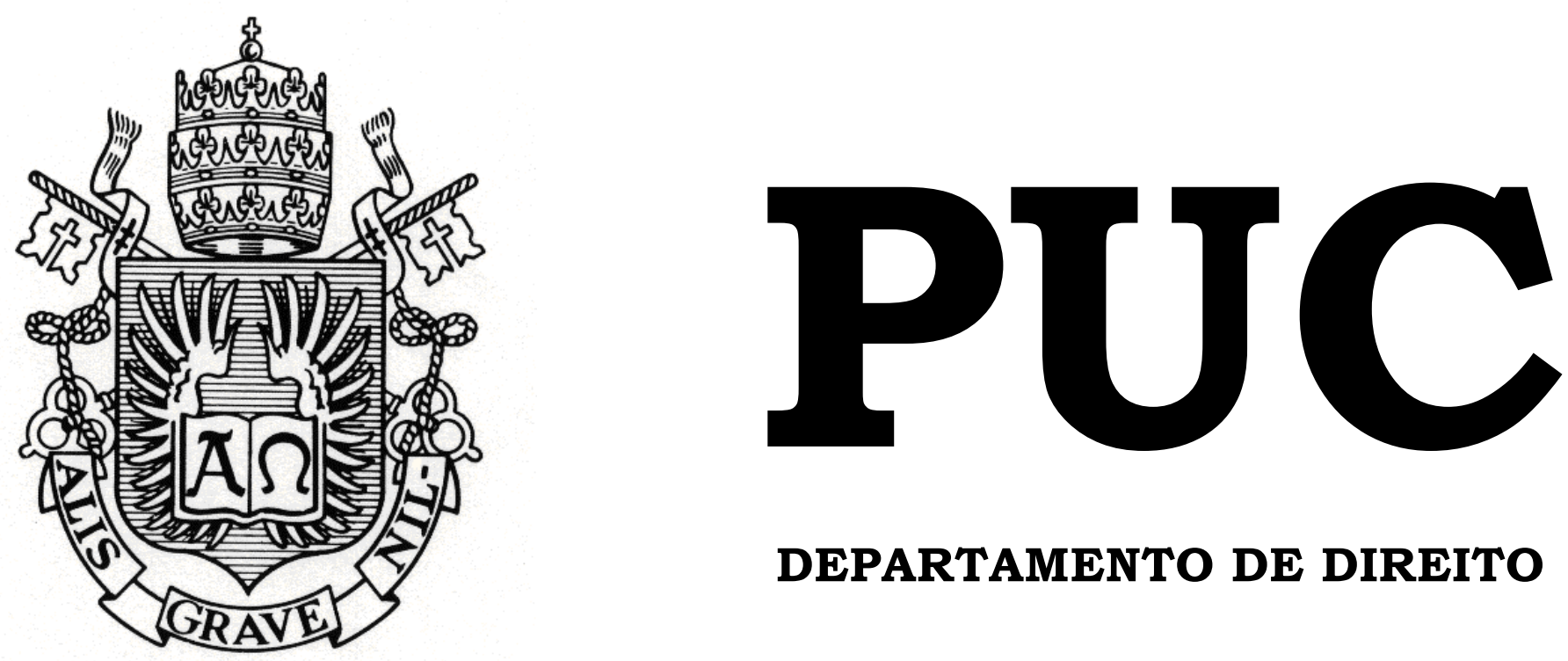

DEPARTAMENTO DE DIREITO

\title{
O CONCEITO DE CONSELHEIRO INDEPENDENTE COMO INSTRUMENTO DE GOVERNANÇA CORPORATIVA
}

\author{
por
}

JOÃO DE MELLO E SOUZA

ORIENTADOR: Francisco Antunes Maciel Müssnich 2015.2

PONTIFÍCIA UNIVERSIDADE CATÓLICA DO RIO DE JANEIRO

RUA MARQUÊS DE SÃO VICENTE, 225 - CEP 22453-900

RIO DE JANEIRO - BRASIL 


\title{
O CONCEITO DE CONSELHEIRO INDEPENDENTE COMO INSTRUMENTO DE GOVERNANÇA CORPORATIVA
}

\author{
por
}

João de Mello e Souza

Monografia apresentada ao Departamento de Direito da Pontifícia Universidade Católica do Rio de Janeiro (PUC-Rio) para a obtenção do Título de Bacharel em Direito.

Orientador(a): Francisco Antunes Maciel Müssnich 


\section{Agradecimentos}

Em primeiro lugar, agradeço aos meus familiares, em especial minha mãe, pai, irmãos e avós, por toda a dedicação, carinho e suporte ao longo da vida. Agradeço por tudo, de coração, sem temer a amplitude que essa palavra possa carregar. Sem vocês, de nada seria capaz.

Não posso deixar de agradecer também aos meus amigos, principalmente àqueles do peito, cuja amizade se iguala à fraternidade. Sem amizades, pouquíssima graça tem a vida, e, neste quesito, posso dizer que sou extremamente afortunado.

Por fim, mas não menos importante, agradeço ao Chico Müssnich, como professor, orientador de monografia e chefe, bem como aos meus demais colegas do BMA Advogados, principalmente ao Amir Bocayuva, à Rafaela Reina e à Karina Lerner, pelo convívio, aprendizado e crescimento diários.

A todos esses, a minha profunda gratidão. 


\section{RESUMO}

A governança corporativa, ou governança interna, passou a ganhar grande destaque e relevância principalmente nas últimas duas décadas. Dentre o que se define como governança corporativa, surge a figura do conselheiro independente como um de seus principais mecanismos. Há enorme discussão acerca dos benefícios e malefícios financeiros que os conselheiros independentes trazem, na prática, às companhias que possuem tais figuras em seus conselhos de administração. Este, todavia, não é o foco do presente trabalho, principalmente por ser um tópico de dificílima constatação empírica, tendo em vista que a performance das companhias é afetada por inúmeros fatores, dentre os quais a existência de membros independentes é apenas mais um.

Não obstante, nestes debates pouco é discutido sobre a essência de independência de tais conselheiros. Afinal, de quem devem ser independentes? De que forma a sua atuação pode ser definida como independente? Será que realmente atuam de forma independente? O conceito sobre a independência dos conselheiros é pacífica ao redor do mundo? Por que são estes considerados um mecanismo de governança corporativa? Que companhias precisam eleger conselheiros independentes, e em que quantidade? Ainda, o que significa governança interna?

O presente trabalho pretende, principalmente, responder a tais perguntas. Em um primeiro momento, é feita uma breve análise do que se entende como governança corporativa, para que se possa entender melhor como esta e a figura do conselheiro independente são indissociáveis. Em sequência, é feita uma análise do mercado de capitais brasileiro e suas

principais características, no qual, para determinadas companhias que ali 
negociam suas ações, a presença de membros independentes é obrigatória no conselho de administração. Aqui, pretende-se uma melhor compreensão do macro ambiente no qual o conselheiro independente deve atuar.

Ainda, é feito um breve resumo do conselho de administração, órgão deliberativo administrativo no qual os conselheiros independentes estão inseridos. Neste momento, também serão indicadas as funções e atribuições aplicáveis aos conselheiros, e, também, será exposto por que os conselheiros independentes e o conselho de administração se tornaram pilares de governança corporativa dentro das companhias.

Por fim, serão detalhados minuciosamente os conceitos de conselheiro independente vigentes no Brasil, bem como será realizada uma comparação com as definições existentes no direito comparado. Com base nas definições verificadas, e na sua comparação, serão, finalmente, apontadas algumas ressalvas e críticas feitas pela doutrina, além de serem apresentadas algumas tendências contemporâneas sobre o tema.

Palavras chave: Direito Societário - Sociedade Anônima - Governança Corporativa - Conselho de Administração - Conselheiro Independente Mercado de Capitais - Segmentos Especiais. 


\section{SUMÁRIO}

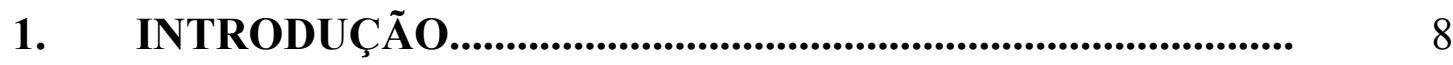

2. GOVERNANÇA CORPORATIVA........................................... 10

2.1. Conceitos e origem....................................................... 10

2.2. O Problema dos Conflitos de Agência............................. 14

3. O MERCADO DE CAPITAIS BRASILEIRO, SUAS CARACTERÍSTICAS, SEGMENTOS E O PAPEL DO CONSELHEIRO INDEPENDENTE.................................................. 16

3.1. Breve Evolução Histórica.................................................. 16

3.2. Fenômeno da listagem nos Segmentos Especiais da 18 BM\&FBOVESPA

3.3. A concentração de propriedade acionária no Brasil e o 20 crescimento dos Segmentos Especiais.

3.4. O papel do Conselheiro Independente nos diferentes 28 cenários de distribuição acionária

4 CONSELHO DE ADMINISTRAÇÃO E GOVERNANÇA 33 CORPORATIVA.

4.1. O Conselho de Administração, e Competências e 33 Funções dos Conselheiros.

4.2. Por que o Conselho de Administração e o Conselheiro 37 Independente se tornaram pilares da Governança Corporativa...

5. O CONSELHEIRO INDEPENDENTE................................... 39

5.1. Conceitos de Conselheiro Independente no Brasil............ 40

5.1.1. O Conceito do IBGC .............................................. 40

5.1.2. O Conceito da CVM.............................................. 43 
5.1.3. O Conceito da BM\&FBOVESPA............................. 45

5.2. Conceitos de Conselheiro Independente no Direito 49

Comparado.

5.2.1. CalPERS ........................................... 49

5.2.2. NYSE .............................................. 53

5.2.3. China.......................................... 56

5.2.4. Portugal............................................................... 58

5.2.5. Alemanha............................................................. 60

5.3. Ressalvas ao Conceito da BM\&FBOVESPA, críticas 61 doutrinárias e questões atuais e correlatas....................................

6. CONCLUSÃO............................................................................. 72

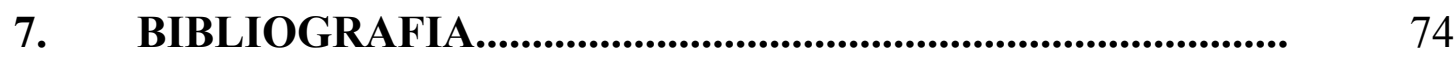

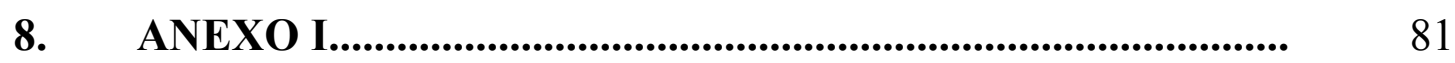




\section{Lista de Abreviações}

"BM\&FBOVESPA" - Bolsa de Valores, Mercadorias e Futuros;

"Código de Governança" - Código de Melhores Práticas de Governança Corporativa do IBGC;

"CVM" - Comissão de Valores Mobiliários;

"IBGC" - Instituto Brasileiro de Governança Corporativa;

"Lei das S.A." - Lei n ${ }^{\circ} 6.404 / 1976$;

"NYSE" - New York Stock Exchange; e

"SEC" - Securities Exchange Commission. 


\section{INTRODUÇÃO}

É indiscutível o fato de que o tema da governança corporativa, ao longo dos últimos anos, vem recebendo grande atenção e relevância nas discussões doutrinárias como, de maneira geral, um conjunto de medidas que visam harmonizar a relação entre acionistas e gestores, bem como a relação entre acionistas majoritários e minoritários, de forma que os fornecedores de recursos financeiros a uma companhia tenham maior segurança no retorno de seu investimento.

O conselho de administração de companhias, por sua vez, é considerado pacificamente como um dos maiores e mais importantes mecanismos e instrumentos de governança interna existentes, tendo em vista a sua posição chave dentro da organização das companhias. É neste órgão que são mitigados os conflitos entre acionistas e administradores, na qualidade de representados e representantes, através da fiscalização que deve ser feita sobre os administradores e é expressa na Lei. Ainda, no caso de companhias de controle acionário concentrado em um único acionista controlador, o conselho de administração também tem a função de fiscalizar sua atuação, o que deve ser feito sob um ponto de vista isento de pressões, estritamente profissional, técnico e desvinculado de interesses e influências externas. De maneira geral, portanto, a atuação fiscalizadora dos membros do Conselho de Administração deve ser, acima de tudo, independente.

É neste cenário que surgem o conceito e a figura do conselheiro independente, como instrumento imprescindível para uma plena efetividade de governança. A leitura sobre o tema se multiplicou rapidamente durante os

últimos anos, a fim de se discutir a efetividade do conselheiro independente como prática de boa governança, e os seus efeitos no desempenho das 
companhias, no valor de suas ações, no monitoramento da administração da companhia, entre outros. Todavia, ainda é escasso em sede de doutrina, principalmente nacional, abordagens sobre o conceito de conselheiro independente, bem como se o conceito atualmente utilizado sobre este é condizente com o que se espera de tal profissional.

O presente trabalho, consequentemente, pretende iluminar este aspecto ainda um tanto quanto obscuro sobre os conselheiros independentes, trazendo à discussão os diferentes conceitos existentes no Brasil e no mundo, com vistas a uma verificação se o conceito atualmente utilizado no país é moderno, harmônico com os conceitos existentes no exterior, e se consegue garantir a efetiva independência dos conselheiros no exercício de suas funções legais e estatutárias. 


\section{GOVERNANÇA CORPORATIVA}

\subsection{Conceitos e Origem}

A governança corporativa, governança interna, ou ainda "corporate governance", em seu termo original, "tem por objetivo precípuo a ampla divulgação de informações (full disclosure) e a redução dos conflitos de agência entre acionistas e administradores". 1 De forma mais específica, SILVEIRA conceitua governança corporativa da seguinte maneira:

A governança corporativa (...) pode ser definida como o conjunto de mecanismos internos e externos que visam harmonizar a relação entre gestores e acionistas, dada a separação entre controle e propriedade. (...) Entre as principais práticas constantes da maioria dos códigos de governança, estão a necessidade de uma participação ativa e independente do Conselho de Administração, o fornecimento de informações precisas e transparentes para o mercado e igualdade de direitos entre todos os acionistas. ${ }^{2}$

Por sua vez, LOBO define a governança interna como:

o conjunto de normas, consuetundinárias e escritas, de cunho jurídico e ético, que regulam os deveres de cuidado, diligência, lealdade, informação e não intervir em qualquer operação em que tiver interesse conflitante com o da sociedade; o exercício das funções, atribuições e poderes dos membros do conselho de administração, da diretoria executiva, do conselho fiscal e dos auditores externos e o relacionamento entre si e com a própria sociedade, seus acionistas e o mercado em geral. ${ }^{3}$

Importante conceito também é apresentado pelo IBGC, que oferece recomendações sobre este tema ao mercado e traz a seguinte definição em seu código de melhores práticas:

sistema pelo qual as organizações são dirigidas, monitoradas e incentivadas, envolvendo os relacionamentos entre proprietários, Conselho de Administração,

\footnotetext{
${ }^{1}$ DA SILVA, Thiago José; DE CAMARGO, André Antunes Soares. Conselheiros Independentes -

${ }^{2}$ SILVEIRA, Alexandre di Miceli, Governança Corporativa, Desempenho e Valor da Empresa no Brasil. São Paulo. 2002. Tese (Mestrado em Economia). Faculdade de Economia, Administração e Contabilidade da Universidade de São Paulo (USP). pp 1-2.

${ }^{3}$ LOBO, Jorge. Princípios de governança corporativa. Revista de Direito Mercantil, Industrial, Econômico e Financeiro, no. 142. São Paulo: Malheiros. Pp. 141-154.
} 
Diretoria e órgãos de controle. As boas práticas de Governança Corporativa convertem principios em recomendações objetivas, alinhando interesses com a finalidade de preservar e otimizar o valor da organização, facilitando seu acesso a recursos e contribuindo para sua longevidade. ${ }^{4}$

Vale destaque também o ensinamento de ADAMEK sobre os princípios de governança aplicáveis aos administradores, segundo o qual:

Em tempos mais recentes os deveres dos administradores novamente se tornaram assunto do momento (...), sinalizando a necessidade de adotar procedimentos de boa gestão societária tendentes a garantir que os administradores atuem realmente no interesse dos sócios e, atualmente, sopesem os interesses de colaboradores da empresa (stakeholders), em especial os trabalhadores. Preconiza-se, por esse movimento (...) o reforço dos deveres fiduciários(...) e das medidas de transparência (disclosure); o aperfeiçoamento dos sistemas de informações sobre a gestão social (accountability) e dos mecanismos de fiscalização e controle (sobretudo com a presença de conselheiros independentes, sem funções executivas); a melhor divisão de poderes e atribuição dos órgãos, visando a preservar a independência de cada qual; e a implementação de várias medidas tendentes a devolver à assembleia geral o papel central que tradicionalmente sempre lhe reconheceu. ${ }^{5}$

Quanto ao princípio de disclosure, acima mencionado por ADAMEK, e intrínseco à boa governança interna, a definição EIZIRIK nos parece pontual:

O princípio de disclosure baseia-se na presunção de que uma vez adequadamente provido das informações relevantes sobre a companhia e os títulos emitidos, o investidor tem condições de avaliar o mérito do empreendimento e a qualidade dos papéis. ${ }^{6}$

Sendo assim, é mister a constatação de que, indiferentemente da definição adotada, tais mecanismos são de inafastável importância para o desenvolvimento e consolidação do mercado acionário de maneira geral, para a captação de recursos às companhias cujas ações ali são negociadas, pautados na ampla e igual divulgação de informação, de forma que exista maior segurança aos investidores sobre as companhias e ações nas quais pretendem

\footnotetext{
4 Instituto Brasileiro de Governança Corporativa. Código de Melhores Práticas de Governança Corporativa. 4a ed. São Paulo: IBGC, 2009.

5 ADAMEK, Marcelo Vieira von. Responsabilidade dos Administradores de S.A. e as Ações Correlatas. São Paulo: Saraiva, 2009. 116 p.

6 EIZIRIK, Nelson; GAAL, Adriana B; PARENTE, Flávia; HENRIQUES, Marcus de Freitas. Mercado de Capitais. Regime Jurídico. Rio de Janeiro: Renovar. 2011. 485 p.
} 
investir. Não é à toa, portanto, que a adoção de instrumentos de governança interna é entendida de forma unânime ao redor do globo como um dos pilares de um mercado de capitais bem desenvolvido e lucrativo.

Não obstante não haver uma definição única e unânime de governança corporativa, sua origem é clara: a governança corporativa foi primeiramente idealizada nos Estados Unidos da América durante a década de 80. O primeiro embrião do que viria a se tornar o abrangente conceito de governança interna que hoje é conhecido teve origem em um caso envolvendo o fundo de pensão americano "Calpers (CaliforniaPublicEmployeesRetirement System)", que elaborou o primeiro rol de práticas de boa governança corporativa após estar envolvida em um caso com a Texaco, renomada companhia do ramo petrolífero em que possuía investimentos. Neste caso, uma tentativa de aquisição da Texaco pela Chevron, outra companhia petrolífera, que seria benéfica aos acionistas da Texaco, foi inviabilizada pelos administradores em benefício exclusivamente próprio, através de táticas defensivas. Começa então a ganhar corpo uma postura mais ativa dos investidores, que, ao invés de simplesmente utilizarem um mecanismo de saída em caso de insatisfação com o investimento feito, passaram a exigir práticas mais adequadas das companhias nas quais investiram, de forma a maximizar os aportes realizados. ${ }^{7}$

Apenas ao longo dos anos 90, todavia, é que o tema da governança corporativa ganha verdadeira ênfase, como consequência de crises financeiras mundiais (como por exemplo aquelas vividas em países como Brasil e Rússia, além da Ásia, de maneira geral) e de grandes escândalos corporativos ocorridos nos Estados Unidos (sendo os casos da Enron e WorldCom os mais notórios). Neste cenário, pôde-se observar como economias de países inteiros

\footnotetext{
${ }^{7}$ SILVEIRA, Alexandre di Miceli. Governança Corporativa no Brasil e no Mundo - teoria e prática. Rio de Janeiro: Elsevier, 2010.
} 
podem ser diretamente afetadas pelo desempenho de grandes companhias e pelos valores de suas ações, como de fato ocorreu sistematicamente em todo sistema financeiro mundial, por questões envolvendo fragilidades nas práticas de governança corporativa.

Sobre os famosos casos Enron e WorldCom, relatam BULHÕES PEDREIRA e LAMY FILHO:

As críticas ao regime das macroempresas controladas pelos administradores, especialmente sob o aspecto da insuficiência de mecanismos de controle de executivos, generalizaram-se e aumentaram de intensidade a partir da divulgação, após a quebra da Enron, no ano 2000, dos abusos cometidos em muitas companhias norte-americanas, e algumas europeias, em termos de fraudes em demonstrações financeiras, com suposta conveniência de empresas de auditoria; empréstimos de interesse de executivos, e nivel de remuneração paga aos executivos, inclusive sob a forma de opções. Esses acontecimentos, que levaram à falência da Enron e de outras companhias, bem como à dissolução da empresa de auditoria Arthur Andersen, deram origem a inquéritos administrativos, ações judiciais de indenização; processos criminais contra administradores e auditores; à votação da lei designada Sarbanes-Oxley e à intensificação dos esforços para a uniformização internacional dos princípios e normas contábeis. 8

Adicionalmente às crises financeiras da década de 90, mais recentemente, a crise financeira global iniciada nos Estados Unidos no ano de 2008, e que até hoje apresenta reflexos nocivos em economias ao redor do globo, também teve como mecanismo de resposta, obviamente entre outras práticas de natureza financeira, a atualização da legislação americana concernente a práticas de boa governança. Nota-se a tendência e o movimento mundial de reconsideração da importância do papel das práticas de boa governança nos mercados de capitais como resposta a crises financeiras, como aconteceu, por exemplo, nos Estados Unidos, com a aprovação da lei Sarbanes-Oxley $A c t^{9}$ (no ano de 2002) como contrapeso às controvérsias

\footnotetext{
${ }^{8}$ BULHÕES PEDREIRA, José Luiz; LAMY FILHO, Alfredo, Direito das Companhias, volume I. Rio de Janeiro: Forense. 2010, p. 112.

${ }^{9}$ Disponível em http://uscode.house.gov/download/pls/15C98.txt.
} 
suscitadas nos escândalos Enron e WorldCom, supramencionadas, bem como a Dodd-Frank $A c t^{10}$ (no ano de 2010) em resposta à crise financeira de 2008, a qual estabeleceu novas exigências práticas de boa governança, e que foi acompanhada pela aprovação de novas regras pela Bolsa de Valores de Nova Iorque (New York Exchange Comission - NYSE).

\subsection{O problema dos conflitos de agência}

A criação do conselheiro independente como instrumento de governança interna tem origem, nos Estados Unidos, no que foi definido como agency problem, ou conflito de agência, e que é, fundamentalmente, um imbróglio entre representantes e representados. BULHÕES PEDREIRA e LAMY FILHO ${ }^{11}$ trazem a lição de que tal conflito foi primeiramente formulado por BERLE ${ }^{12}$, ao constatar, em meio à crescente pulverização das ações das grandes companhias americanas, o fenômeno da separação entre o poder de controle e a propriedade das ações. Neste sentido, verificou-se que, ao passo em que grandes companhias americanas cresciam em número de acionistas e capital, aumentava a distância entre esta grande quantidade de acionistas e a administração da companhia, a qual, por diversas vezes, tomava decisões em benefício próprio e em detrimento aos acionistas, que foram os investidores da companhia e esperam um retorno financeiro sobre o aporte financeiro feito. Neste sentido, o conselho de administração, e mais especificamente o conselheiro independente, seriam instrumento de governança com a função primordial fiscalizar da atuação da diretoria, para que esta tomasse decisões em proveito dos acionistas da companhia.

\footnotetext{
10 Disponível em http://www.sec.gov/about/laws/wallstreetreform-cpa.pdf

${ }^{11}$ BULHÕES PEDREIRA, José Luiz; LAMY FILHO, Alfredo. Op. Cit.. 784 p.

${ }^{12}$ BERLE, Adolf; MEANS, Gardiner. Modern Corporation and Private Property. 10 ${ }^{\mathrm{a}}$ ed Londres: Transaction Pub. 2010. p. 358-359.
} 
No entanto, apesar de sua origem, os conflitos de agência não estão restritos a companhias de capital pulverizado. Nas companhias de estrutura concentrada, por sua vez, ainda que do ponto de vista prático a administração da companhia não seja fonte de poder prevalecente (a não ser em casos raros de absenteísmo do acionista controlador), o conselho de administração representa um intermediário essencial e estratégico na por muitas vezes conflituosa relação entre acionistas minoritários e controladores. ${ }^{13}$ Portanto, independentemente das estruturas de capital e conflitos supramencionados, o poder da administração exerce papel crucial nas sociedades anônimas, como fonte de poder prevalecente (capital pulverizado) ou intermediário (controle definido).

De modo a minimizar o conflito de agência, deve a administração da companhia funcionar de forma autônoma e independente, como apontado por CEREZETTI:

(...) o recurso aos administradores independentes apresentou-se, então, como uma das medidas utilizadas para proteger acionistas dos prejuízos decorrentes de a companhia ser conduzida em prol dos interesses dos seus próprios gerentes, sob a crença de que os conselheiros assim denominados estariam capacitados a cumprir sem conflito as funções a eles atribuidas.

Ao contrário do que se poderia imaginar, esta constatação não leva à conclusão de que a transposição da técnica para cenários de concentração acionária, como o brasileiro, ocasiona sua perda de sentido. Na verdade, a nomeação de administradores independentes nestes casos também serve para combater os efeitos deletérios do controle, servindo para fornecer proteção contra a extração de indevidos beneficios particulares pelo acionista controlador. ${ }^{14}$

\footnotetext{
${ }^{13}$ DA SILVA, Thiago José; DE CAMARGO, André Antunes Soares. Op. Cit. 41p.

14 CEREZETTI, Sheila Christina Neder. Administradores Independentes e Independência dos administradores (regras societárias fundamentais ao estímulo do mercado de capitais brasileiro). In: VON ADAMEK, Marcelo Vieira (Coord.) Temas de Direito Societário e Empresarial Contemporâneos. São Paulo: Editora Malheiros. 2011. p. 582-583.
} 


\section{Mercado de capitais brasileiro, suas características, segmentos e o papel do Conselheiro Independente.}

\subsection{Breve Evolução Histórica}

O mercado de capitais brasileiro foi de lenta evolução durante o século XX. Antes da década de 60, o investimento principal dos brasileiros eram ativos reais (imóveis), em um cenário no qual aplicações em títulos públicos ou privados não eram recorrentes. Essa situação começou a se modificar quando o governo militar, que assumia o poder em 1964, iniciou um programa de grandes reformas na economia nacional, dentre as quais figurava a reestruturação do mercado financeiro, quando diversas novas leis foram editadas neste sentido. Podemos destacar, dentre aquelas que tiveram maior importância para o mercado de capitais, a Lei $\mathrm{n}^{\circ} 4.537 / 64^{15}$, que instituiu a correção monetária, a Lei $\mathrm{n}^{\circ} 4.595 / 64^{16}$, que criou o Conselho Monetário Nacional e o Banco Central, e, principalmente, a Lei ${ }^{\circ} 4.728 / 65^{17}$, a primeira Lei de Mercado de Capitais, que disciplinou este mercado e estabeleceu medidas para o seu desenvolvimento.

As décadas de 70 e 80 foram de alguma turbulência, com momentos de altas e baixas para o mercado de capitais. Durante o início da década 70 foram introduzidos alguns incentivos fiscais para a aplicação no mercado acionário, o que levou a um rápido crescimento da demanda por ações pelos investidores sem que houvesse aumento simultâneo de novas emissões de ações por essas empresas. Tal combinação resultou em um "boom" na Bolsa do Rio de Janeiro, em uma verdadeira onda especulativa que manchou a reputação do mercado acionário por algum tempo. Foi nesta época, inclusive, que foram introduzidas

\footnotetext{
${ }^{15}$ Disponível em: http://www.planalto.gov.br/ccivil_03/leis/L4357.htm.

${ }^{16}$ Disponível em: http://www.planalto.gov.br/ccivil_03/leis/L4595.htm.

${ }^{17}$ Disponível em: http://www.planalto.gov.br/ccivil_03/LEIS/L4728.htm.
} 
duas importantíssimas novas normas legais, que até hoje estão em vigor: a Lei das S.A., e a Lei ${ }^{\circ} 6.385 / 76^{18}$, a segunda Lei do Mercado de Capitais, que, entre outras inovações, criou a CVM, cujo principal papel é regulamentar e desenvolver o mercado de capitais, fiscalizar as bolsas de valores e as companhias abertas, nos termos do artigo $8^{\circ}$ desta $1 \mathrm{ei}^{19}$.

O final da década de 80 e início da década de 90 foram essenciais no processo de internacionalização do mercado, com a aceleração do movimento de abertura da economia brasileira e do volume de investidores estrangeiros atuando no mercado de capitais brasileiro. Neste momento, algumas empresas brasileiras começaram a buscar o mercado externo como meio de capitalização, através da listagem de suas ações em bolsas de valores estrangeiras, com maior destaque para a NYSE, sob a forma de american depositary receipts. Com este movimento, as companhias abertas brasileiras foram forçadas a obedecer regras impostas pela SEC, órgão regulador do mercado de capitais norte-americano e comparável, guardadas as devidas peculiaridades, com a CVM brasileira. Tais regras envolviam, basicamente, aspectos contábeis e a transparência e divulgação de informações (disclosure), portanto, princípios de governança corporativa. Sendo assim, tais empresas brasileiras passaram a estabelecer contato com acionistas mais exigentes, sofisticados e rigorosos, acostumados a investir em mercados com maior desenvolvimento de políticas de governança corporativa. Constatada esta

\footnotetext{
18 Disponível em: http://www.planalto.gov.br/ccivil_03/leis/L6385.htm.

19 “Art. $8^{\circ}$ Compete à Comissão de Valores Mobiliários:

I - regulamentar, com observância da política definida pelo Conselho Monetário Nacional, as matérias expressamente previstas nesta Lei e na lei de sociedades por ações;

II - administrar os registros instituidos por esta Lei;

III - fiscalizar permanentemente as atividades e os serviços do mercado de valores mobiliários, de que trata o Art. $1^{\circ}$, bem como a veiculação de informações relativas ao mercado, às pessoas que dele participem, e aos valores nele negociados;

IV - propor ao Conselho Monetário Nacional a eventual fixação de limites máximos de preço, comissões, emolumentos e quaisquer outras vantagens cobradas pelos intermediários do mercado;

$V$ - fiscalizar e inspecionar as companhias abertas dada prioridade às que não apresentem lucro em balanço ou às que deixem de pagar o dividendo mínimo obrigatório."
} 
disparidade no nível de desenvolvimento e maturidade dos mercados de capitais estrangeiros e o nacional, ficou o mercado de capital brasileiro em descrédito, em um contexto de pouca proteção ao acionista minoritário e incertezas quanto ao retorno do investimento realizado. Foram implementadas, então, iniciativas institucionais e governamentais para assegurar melhores práticas de governança, dentre as quais iluminamos as alterações feitas na Lei das S.A. e na Lei de Mercado de Capitais pela Lei n 10.303/2001 e a criação pela BM\&FBOVESPA dos segmentos especiais, notadamente o Novo Mercado e os Níveis 1 e 2 de governança corporativa. Adicionalmente, no ano de 2007 , foi criado também um novo segmento, denominado Bovespa Mais. ${ }^{20}$

\subsection{Fenômeno da listagem nos Segmentos Especiais da BM\&FBOVESPA.}

Atualmente, após as mudanças supramencionadas ocorridas na virada do século, as empresas cujas ações são negociadas na B\&FBOVESPA podem aderir voluntariamente a práticas de governança interna mais fortes, podendo então ser classificadas, basicamente, em quatro níveis: Nível 1, Nível 2, Novo Mercado e Bovespa Mais. Cada um desses níveis tem regras e exigências particulares de governança corporativa, sendo o Novo Mercado o segmento de regras mais fortes, como, por exemplo, a exigência de que todas as ações das companhias ali listadas atribuam direito de voto nas Assembleias Gerais, de forma que a propriedade acionária e poder político sejam indissociáveis. No tocante à criação do Novo Mercado, PRADO e VILELA sintetizam a opinião majoritária da doutrina especializada e do mercado: “(...) é possível afirmar que este segmento foi o grande divisor de águas no Brasil em relação à

\footnotetext{
${ }^{20}$ Mercado de Valores Mobiliários Brasileiro - Comissão de Valores Mobiliários.Rio de Janeiro, 2014. Pp. 56-59.
} 
introdução, na prática, de modelos de boa governança corporativa." ${ }^{21} \mathrm{~A}$ tabela apresentada na forma do Anexo I do presente trabalho ilustra em detalhes as exigências de cada segmento de listagem da BM\&FBOVESPA. ${ }^{22}$

Por sua vez, SALOMÃO FILHO tece os seguintes comentários sobre o Novo Mercado:

A proposta do Novo Mercado repousa sobre três bases principais. A primeira base principal sem dúvida é a informação completa. Os requisitos de informação previstos no regulamento vão muito além dos previstos na lei societária. A segunda viga de sustentação é o reforço das garantias patrimoniais dos minoritários no momento de saída da sociedade. É só na terceira linha de sustentação que se nota algo de verdadeiramente original. Trata-se das chamadas proteções estruturais, por modificar a própria conformação interna das sociedades. Não são diretamente inspirados pelo princípio cooperativo, mas sem dúvida ajudam a persegui-lo ao enfraquecer ou permitir o enfraquecimento do poder do controlador ${ }^{23}$

Como pode ser observado, dentre as exigências de governança interna impostas às companhias listadas no Novo Mercado e no Nível 2, além de medidas importantes como esforços para a dispersão acionária e um percentual mínimo de ações em free float, está a imposição de conselhos de administração compostos de ao menos 5 membros, dos quais pelo menos $20 \%$ devem ser conselheiros independentes com mandato unificado de até 2 anos. Sendo assim, resta claro que a eleição de membros independentes ao Conselho de Administração é um dos principais instrumentos de governança interna atualmente existentes, intrínseco aos dois segmentos de maior exigência quanto à boa governança. Todavia, como se verá de forma mais detalhada adiante no Capítulo 5 deste trabalho, o conceito atualmente utilizado para a

${ }^{21}$ PRADO, Roberta Nioac; VILELA, Renato. Apontamentos sobre a evolução do Conselho de Administração no Brasil a partir dos anos 1980. In: FONTES FILHO, Joaquim Rubens; CAMARA LEAL (Coord.). Governança Corporativa: discussões sobre os conselhos em empresas no Brasil. São Paulo: Saint Paul. 2012. 265 p.

22 Disponível em http://www.bmfbovespa.com.br/pt-br/servicos/solucoes-para-empresas/segmentosde-listagem/o-que-sao-segmentos-de-listagem.aspx?idioma=pt-br. Acessado em 24 de setembro de 2015.

${ }^{23}$ SALOMÃO FILHO, Calixto. O Novo Direito Societário. $4^{\text {a }}$ ed. São Paulo: Malheiros. 2011. Pp. 6970. 
classificação de "independente" a membros eleitos sofre algumas críticas quando verificada a sua aplicabilidade prática e o efetivo alcance aos objetivos que eram esperados quando da criação de tal figura e conceito.

\subsection{A concentração de propriedade acionária no Brasil e o crescimento dos Segmentos Especiais}

Análises feitas do mercado acionário brasileiro constatam facilmente que este é de alta concentração de propriedade acionária, sendo esta, inclusive, uma tradição histórica. Tal característica, por sua vez, é contrária à realidade americana, cujo mercado de capitais, considerado por muitos o mais desenvolvido e lucrativo do mundo, tem como uma das suas principais características a grande dispersão acionária. Em termos práticos, verifica-se que no Brasil a grande maioria das companhias com ações negociadas em bolsa de valores têm um acionista, ou um grupo de acionistas, que exerce o poder de controle definido no artigo 116 da Lei das S.A. nos seguintes termos:

Art. 116. Entende-se por acionista controlador a pessoa, natural ou jurídica, ou o grupo de pessoas vinculadas por acordo de voto, ou sob controle comum, que:

a) é titular de direitos de sócio que lhe assegurem, de modo permanente, a maioria dos votos nas deliberações da assembleia-geral e o poder de eleger a maioria dos administradores da companhia; $e$

b) usa efetivamente seu poder para dirigir as atividades sociais e orientar o funcionamento dos órgãos da companhia.

Parágrafo único. O acionista controlador deve usar o poder com o fim de fazer a companhia realizar o seu objeto e cumprir sua função social, e tem deveres e responsabilidades para com os demais acionistas da empresa, os que nela trabalham e para com a comunidade em que atua, cujos direitos e interesses deve lealmente respeitar e atender.

Neste sentido, o Brasil tem convivido com um mercado de capitais que por muitos é considerado ainda como subdesenvolvido, com uma estrutura de propriedade predominantemente concentrada através de grandes 
conglomerados de famílias tradicionais, que em muitos casos utilizam do seu poder político para impedir reformas de governança corporativa na legislação aplicável. Inclusive, pesquisas sobre a experiência brasileira na década de 90 concluíram que a baixa proteção a investidores minoritários, aliada à pouca relevância dada a práticas de boa governança corporativa eram as grandes responsáveis pela ausência de ofertas públicas de ações, os IPO's, e pelos baixos volumes de negociação no mercado nacional ${ }^{24}$, e tais pesquisas foram decisivas para a criação dos segmentos especiais de listagem pela BM\&FBOVESPA em 2000.

Fato é que, desde então, a realidade de grande concentração acionária brasileira vem evoluindo, mas em ritmo razoavelmente lento. Considerando-se os incentivos à dispersão acionária e à circulação de ações em free float impostas às companhias listadas no Novo Mercado e no Nível 2, seria coerente o entendimento de que, quanto mais evoluídos tais segmentos, quanto maior o número de companhias ali negociando suas ações, menor é a tendência à concentração acionária. Traduzindo-se esta evolução em números, contata-se que, enquanto no ano de 2003 havia apenas 2 empresas negociando suas ações no Novo Mercado e 2 empresas negociando suas ações no segmento especial Nível $2^{25}$, em 2007 tais números já haviam saltado para 92 empresas no Novo Mercado e 20 no Nível $2^{26}$. Em 2012, 128 companhias atuavam no Novo Mercado e 20 no Nível $2 .{ }^{27}$ Em contínua evolução, em outubro de 2015, este

\footnotetext{
${ }^{24}$ DE CARVALHO, Antonio Gledson. Ascensão e Declínio do Mercado de Capitais no Brasil: A Experiência dos Anos 90. São Paulo. 2000. Disponível em http://ssrn.com/abstract=1010732

${ }^{25}$ GELMAN, Marina Oehling. O Conceito de Conselheiro Independente vigente na Regulamentação dos Niveis Diferenciados de Governança Corporativa da BM\&FBOVESPA. 2012. p. 53. Tese (Mestrado em Direito) - Fundação Getúlio Vargas (FGV-SP)

26 GELMAN, Marina Oehling. op cit. p. 54

${ }^{27}$ GELMAN, Marina Oehling. op cit. p. 55
} 
número atingiu, para o Novo Mercado, nada menos que 131 companhias, e, para o Nível 2, foi mantido o número de 20 companhias $^{28}$.

Este quadro de evolução revela não apenas o crescimento das empresas listadas, mas que este crescimento ocorreu principalmente no Novo Mercado, que é o segmento especial de práticas de governança mais exigentes. Portanto, é notável o prestígio atribuído a companhias que adotam as práticas de governança interna do Novo Mercado, e como a compra de ações destas companhias está se tornando cada vez mais uma opção viável de investimento no País.

Todavia, frisa-se que, apesar de ser um indício de maior dispersão acionária, o crescimento do Novo Mercado não significa necessariamente que os tradicionais conglomerados de controle estão sendo substituídos por uma efetiva estrutura de capital pulverizado. GORGA, em pesquisa sobre o tema, constatou no ano de 2009 que 85\%, ou seja, a grande maioria das empresas listadas no Novo Mercado fizeram ali a sua primeira oferta pública de ações, ou seja, abriram o seu capital diretamente neste segmento, são "novas entrantes". Consequentemente, conforme a referida autora, não seriam companhias tradicionalmente participantes do mercado de capitais e que estão mudando seu padrão de comportamento para adotarem melhores práticas de governança, tampouco que alteraram de forma significativa a sua estrutura de propriedade. $^{29}$

\footnotetext{
28 Dados disponíveis em: http://www.bmfbovespa.com.br/cias-listadas/EmpresasListadas/BuscaEmpresaListada.aspx?indiceAba=2\&seg=BM\&Idioma=pt-br. Acessado em

${ }^{29}$ GORGA, Érica. Changing the paradigm of stock ownership from concentrated towards dispersed ownership? Evidences from Brazil and consequences for emerging countries. In: Northwestern Journal of International Law \& Business, v.29. 10-11 pp. Disponível em http://papers.ssrn.com/sol3/papers.cfm?abstract_id=1121037. Acessado em 15/09/2015.
} 
Como aludido, esta estrutura de propriedade concentrada é de tradição histórica no Brasil. No ano de 1996, VALADARES e LEAL ${ }^{30}$ constataram que, dentre as 325 companhias listadas na BMF\&BOVESPA naquele ano, em média, um único acionista detinha $41 \%$ por cento do capital total, o que ainda era aliado a uma disseminação de ações sem direito a voto, que, de acordo com os autores supramencionados, era refletido no fato de que apenas $11 \%$ daquelas companhias não possuíam ações sem direito a voto. Vale lembrar que, para uma companhia negociar suas ações no Novo Mercado, todas as suas ações devem conceder o direito a voto. Além disso, foi verificado por tais autores à época de tal pesquisa que $62,5 \%$ das empresas tinham um único acionista com mais de $50 \%$ do capital votante, e, das companhias restantes nas quais não se verificava a figura deste acionista controlador, o maior acionista detinha, em média, $32 \%$ do capital votante.

Em outro estudo posterior sobre o tema, CARVALHAL e LEAL, ao se debruçarem sobre o ano de 2000 e atualizarem os dados anteriormente verificados, constataram que, em uma amostra de 225 companhias, incríveis 90\% possuíam um único acionista com mais da metade do capital votante. Ainda, dentre as companhias que não tinham um acionista majoritário desta magnitude, o maior acionista detinha, em média, $37 \%$ do capital votante. ${ }^{31}$ Resta evidente, portanto, não apenas a alta concentração acionária, mas também praticamente a ausência de qualquer evento de pulverização antes da criação dos segmentos especiais de listagem pela BM\&FBOVESPA.

Após a criação dos segmentos especiais de listagem da BM\&FBOVESPA, no final do ano de 2000, esta característica do mercado

30 VALADARES, Silvia Mourthe; LEAL, Ricardo P.C. Ownership and Control Structure of Brazilian Companies. Sem data. Disponível em http://ssrn.com/abstract=213409 . Acessado em 15/09/2015.

31 CARVAlHAL, André da Silva; LEAL, Ricardo P.C. Corporate Governance, Market Valuation and Dividend Policy in Brazil. Coppead Working Papers No. 390. 2003. Disponível em http://ssrn.com/abstract=477302. Acessado em 15/09/2015. 
brasileiro evoluiu razoavelmente, com grande impacto ocasionado pelo “boom" de IPO's acontecido nos anos de 2006 e 2007. Neste novo ambiente, com a possibilidade de negociação de ações nos segmentos especiais criados, GORGA novamente atualizou os dados supramencionados em pesquisa realizada no ano de $2009^{32}$. Tal pesquisa detectou, dentre as 339 companhias listadas na BM\&FBOVESPA, que aquelas operando no mercado tradicional, ou seja, fora dos segmentos especiais de listagem (em um total de 183 companhias), aproximadamente $72,67 \%$ das companhias possuíam um acionista controlador, assim considerado pela autora como um único acionista detentor de mais de $50 \%$ do capital votante, a despeito da definição legal de controle prevista no artigo 116 da Lei das S.A. e acima transcrito. Portanto, no mercado tradicional, não era possível a visualização de grandes avanços. Tal realidade era acompanhada pelos Níveis 1 e 2, dentro dos quais, segundo a autora, respectivamente, $71 \%$ e $70 \%$ possuíam um acionista com mais de 50\% do capital votante, em mais uma demonstração de forte concentração de propriedade acionária de ações com direito a voto. Contudo, a pesquisa desta autora apresenta contornos inovadores ao apresentar os resultados verificados nas companhias listadas no Novo Mercado. Neste, pela primeira vez no Brasil, identificou-se um cenário de maioria de empresas que não possuíam um único acionista controlador. Das 92 companhias então atuantes no Novo Mercado, apenas 27, ou seja, 29\%, detinham um único acionista controlador, no que, aparentemente, demonstraria o progresso do mercado de capitais brasileiro. Todavia, a autora chama especial atenção em seu estudo para o fato de que tais números não levam em consideração os acordos de acionistas voltados para o restabelecimento de controle, também aqui abordados de forma mais detalhada no capítulo 5 quanto aos seus reflexos na atuação dos conselheiros

\footnotetext{
32 GORGA, Érica. Changing the paradigm of stock ownership from concentrated towards dispersed ownership? Evidences from Brazil and consequences for emerging countries. In: Northwestern Journal of International Law \& Business, v.29. 464 pp. Disponível em http://papers.ssrn.com/sol3/papers.cfm?abstract_id=1121037. Acessado em 15/09/2015.
} 
independentes. De fato, levando-se em conta tais acordos, dentre as 92 companhias então listadas no Novo Mercado, o número de empresas com controle definido passou dos 27 acima mencionados para 47, logo, 51\% das empresas atuantes neste segmento. Sendo assim, com o amplo uso de acordo de acionistas como instrumento de recomposição do controle, nota-se que a tradição brasileira de concentração acionária continua configurando como a realidade da maioria das companhias listadas em todos os segmentos de negociação da BM\&FBOVESPA, do mercado tradicional ao Novo Mercado. Por fim, de acordo com a autora supramencionada, não se pode negar que o Novo Mercado representou um avanço neste sentido, mas o entusiasmo da época quanto a uma possível mudança de paradigma, o que, inclusive, era celebrado pela mídia especializada à época, não deve ser creditado como uma verdade absoluta, visto que, na verdade, não houve uma mudança significativa no perfil de propriedade acionária no Brasil.

Neste sentido, em termos práticos, podemos citar poucas companhias brasileiras que realmente têm o seu capital pulverizado e em negociação no mercado de capitais. Uma movimentação com este objetivo teve início apenas nos anos de 2005 e 2006, nos quais foram presenciadas as primeiras pulverizações de capital pelas companhias Lojas Renner S.A. (2005), Perdigão S.A., Diagnósticos da América S.A., Empresa Brasileira de Aeronáutica S.A. e Submarino S.A. $(2006)^{33}$. Quanto a esta evolução do mercado brasileiro, MORAES fez o seguinte registro:

Impulsionado por este novo cenário, o mercado de valores mobiliários está vivenciando, desde 2005, operações de características inéditas.

A Lojas Renner, por exemplo, converteu todas as ações preferenciais em ordinárias, alterou seu estatuto social segundo as exigências do Novo Mercado e realizou, em

\footnotetext{
${ }^{33}$ MARTINS NETO, Carlos. Dispersão acionária, tomada hostil de controle e poison pills:Breves reflexões. Disponível em: http://www.bocater.com.br/wp-content/uploads/2013/10/artigo-2010-09.pdf. Acessado em 18/09/2015.
} 
junho e julho de 2005, venda pulverizada das ações correspondentes a 96\% do seu capital. A operação representou um autêntico recorde, pois a maioria das companhias brasileiras mantém dispersão de, no máximo, 30\% das ações de sua emissão. A J.C. Penney, Inc., enquanto controlava a Renner, concentrava 97,7\% das ações, deixando um free float de 2,3\%.

No primeiro trimestre de 2006, outras reestruturações societárias vieram a público, trazendo uma novidade importante: a pulverização do controle de companhias abertas. É o que aconteceu com a Perdigão S.A., a Diagnósticos da América S.A. DASA, a Empresa Brasileira de Aeronáutica S.A. - EMBRAER e a Submarino S.A. Submarino. Esse movimento de dispersão acionária contrasta com o de concentração de ações, que caracteriza as empresas brasileiras, ou seja, de consolidação do poder num acionista ou grupo controlador. É uma evolução no sentido da real democratização do capital das empresas, que vem sendo preconizado e estimulado há mais de trinta anos e já é realidade em muitos países. ${ }^{34}$

Em contraposição à realidade brasileira estão os mercados de capitais considerados desenvolvidos, principalmente o mercado acionário americano. Neste país, a dispersão acionária é de tal forma generalizada, que ainda em 1929 algumas companhias já apresentavam um nível de pulverização de seu capital tão grande que a soma das participações dos vinte maiores acionistas representava algo em torno de $5 \%$ do capital da companhia. ${ }^{35}$ HANSMAN e KRAAKMAN descrevem o início da dispersão acionária americana da seguinte forma:

In the United States, this diffusion of share ownership has been underway since the beginning of the twentieth century. It has accelerated substantially in recent years, however. Since the Second War, an ever-increasing number of American workers have had their saving invested in corporate equities through pension funds. ${ }^{36}$

\footnotetext{
${ }^{34}$ MORAES, Luiza Rangel. A pulverização do controle de companhias abertas. Revista de Direito Bancário e do Mercado de Capitais. São Paulo: Revista dos Tribunais, ${ }^{\circ}$ 32, abril-junho/2006, p. 52.

35 BERLE, Adolf A; MEANS, Gardiner C. A moderna sociedade anónima e a propriedade privada. Tradução de Dinah de Abreu Azevedo. São Paulo: Nova Cultural. 1988. 69 p.

${ }^{36}$ HANSMANN, Henry; KRAAKMAN, Reinier. The end of history for corporate law. Georgetown Law Journal, Washington. n. 89, jan. 2001. p. 15
} 


\section{É valiosa, também, a lição de BUHÕES PEDREIRA e LAMY FILHO}

sobre a dispersão acionária tipicamente americana:

(...) Nas companhias gigantes norte-americanas e europeias o grau de dispersão das ações chega ao ponto de os maiores acionistas possuírem, cada um, participação da ordem de $1 \%$ ou $2 \%$ do capital social. Nesse estágio, nenhum acionista - ou grupo de acionistas - tem condições para formar e manter um bloco de controle. Todos são aplicadores de capital - somente se interessam pelos dividendos e pelo valor de mercado de suas ações, e deixam a direção da empresa a cargo dos administradores; raramente comparecem às reuniões da assembleia geral e tendem a manter os administradores nos seus cargos enquanto o funcionamento da companhia é satisfatório. ${ }^{37}$

Quanto à maior credibilidade atribuída a mercados compostos por companhias de capital pulverizado, e a sua relação com princípios de governança que estimulem esta pulverização, GARCIA explica:

De fato, para que os investidores possam sentir-se protegidos e, deste modo, estimulados a injetar capital nas companhias nacionais, é preciso que o Mercado acionário seja forte e que o aparato jurídico seja suficiente para que os investidores vejam defendidos os seus interesses e vedadas as manobras estabelecidas unilateralmente pelos controladores em benefício próprio. ${ }^{38}$

Como será visto a seguir, a definição e o escopo de atuação dos conselheiros varia de acordo com o tipo de concentração acionária nos quais estão inseridos. Igualmente são diferentes os desafios impostos a cada conselheiro, de maneira que não se pode e não se deve fazer uma generalização quanto a este tipo de conselheiro, devendo ser observadas as peculiaridades casuísticas do país nos quais devem atuar.

\footnotetext{
${ }^{37}$ BULHÕES PEDREIRA, José Luiz; LAMY FILHO, Alfredo. Op cit. P. 785.

${ }^{38}$ GARCIA, Letícia Simonetti. O controle nas companhias abertas brasileiras de capital pulverizado. São Paulo. Tese (Doutorado em Direito). PUC-SP. p. 115. Disponível em: http://www.dominiopublico.gov.br/download/teste/arqs/cp062700.pdf . Acessado em 31/09/2015.
} 


\subsection{O papel do Conselheiro Independente nos diferentes cenários de distribuição acionária}

Em face das diferentes características verificáveis nos mercados de capitais brasileiro e americano, refletem-se os conceitos adotados em cada país para o conselheiro independente, como tratado com maior minúcia abaixo no capítulo 5 deste trabalho. Além disso, no entanto, é notório que, além de diferente conceituação, o conselheiro independente atuará, na prática, de forma diferente em cada um desses países.

Nos Estados Unidos, país conhecido pela pulverização de ações como visto acima, e, consequentemente, com ausência de grandes exemplos de companhias dotadas de um acionista controlador bem definido, o conselheiro independente atua de forma predominante para a resolução de conflitos de agência entre os acionistas e os administradores, como exposto acima no capítulo 2.

Por outro lado, observada a realidade brasileira de pouquíssima dispersão acionária e de elevados benefícios privados de controle, o conselheiro independente opera como um garantidor do interesse de todos os acionistas da companhia, por não estar necessariamente atrelado e vinculado ao acionista controlador, pelo menos na teoria. Além disso, deve atuar também como intermediário entre acionistas majoritários e minoritários.

Tal papel do conselheiro independente faz com que, recorrentemente, este seja visto, até com certo desdém, como um mero representante dos 
acionistas minoritários. CLARKE $^{39}$ defende que, apesar da proteção aos acionistas minoritários ser uma das três grandes funções que se espera do conselheiro independente, esta prerrogativa deve ser vista com cautela, visto que ideia do conselho de administração proteger o acionista minoritário contra os grandes acionistas parece de difícil execução para este autor, pois as normas de direito societário são predominantemente elaboradas no sentido de dar aos acionistas controladores o poder de decisão na eleição dos membros do conselho. Entretanto, o referido autor também assevera que até mesmo um único conselheiro independente, isolado, pode garantir aos acionistas minoritários um significativo grau de proteção, ao ter acesso e tomar conhecimento de decisões sobre a companhia, que, caso reflitam casos de abusos pelo grupo de controle, poderiam ser relatadas aos acionistas minoritários. ${ }^{40}$

Outro trabalho interessante que explora a questão do papel do conselheiro independente em empresas controladas é o artigo da americana DEMOTT, o qual versa sobre companhias americanas controladas por grupos familiares $^{41}$. Curiosamente, a autora analisa companhias com um perfil extremamente alinhado com a grande maioria das companhias brasileiras, mas que não é verificado de forma tão vasta em solo ianque, qual seja, o de alta concentração de poder de controle nas mãos de pessoas relacionadas por vínculos familiares. Nestas companhias, segundo a autora, o trabalho de conselheiros independentes se torna ainda mais desafiador, levando-se em consideração que as tensões do ambiente familiar muitas vezes podem se

\footnotetext{
${ }^{39}$ CLARKE, Donald C. Three Concepts of the Independent Director. Delaware Journal of Corporate Law, Vol. 32, $\mathrm{N}^{0}$ 1. 2007. 77 p. Disponível em http://ssrn.com/abstract=975111. Acessado em $19 / 09 / 2015$.

${ }^{40}$ Ibid. p 80.

${ }^{41}$ DEMOTT, Deborah. Guests at the Table: Independent Directors in Family-Influenced Public Companies. Duke Law School Legal Studies Paper No. 165. 2007. Disponível em http://ssrn.com/abstract=1010732. Acessado em 20/09/2015.
} 
refletir nas decisões referentes aos negócios da companhia, em uma verdadeira comunhão entre as histórias das famílias e de seus negócios.

Conforme a autora, o conceito americano de conselheiro independente não apresenta grande apreço pela figura do acionista controlador, ao definir a independência de tal conselheiro principalmente em sua relação com a própria companhia e sua administração, conforme pormenorizado no capítulo 5 do presente, o que torna esta questão ainda mais complexa. A autora entende que, dadas às diferenças notadas entre uma administração "comum" e aquela composta por membros familiares, os conselheiros independentes seriam os únicos com discernimento e imparcialidade para resolver questões difíceis, que implicam em conflito entre laços familiares e necessidades dos negócios da companhia, tais como a sucessão dos administradores, ameaças externas às posições da empresa e a existência separada do núcleo familiar. ${ }^{42}$

Assim sendo, a autora identifica quatro funções relevantes dos conselheiros independentes a serem exercidas em companhias familiares: 1) vigilância em nome do interesse público de acionistas; 2) exercício de uma checagem efetiva que pode contribuir para complementar ou questionar a percepção dos administradores e da família controladora, o que poderá resguardar a primazia das necessidades e interesses da companhia, ao passo que garante que o processo de decisão do alto nível da administração não seja dominado pela dinâmica familiar; 3) servir como intermediário entre família controladora e alta administração, a qual pode ou não ser composta por membros da própria família; e 4) reforçar práticas de governança interna. ${ }^{43}$

\footnotetext{
42 Ibid. pp 6-9.

${ }^{43}$ Ibid. p 45.
} 
Sobre este tema, o professor SECCHI MUNHOZ, defensor das vantagens do sistema de capital concentrado, ao concluir que o sistema de concentração brasileiro pode ser sim eficiente, faz a seguinte ressalva extremamente pertinente à atuação dos conselheiros independentes:

(...) o monitoramento do controlador para impedir, sobretudo, a obtenção de beneficios particulares mediante negócios realizados com a companhia, em detrimento de seu interesse social especifico, indubitavelmente faz-se imprescindivel para assegurar um grau mínimo de eficiência para o sistema de controle concentrado. $^{44}$

GELMAN, em sua dissertação de mestrado envolvendo conselheiros independentes tece as seguintes considerações pontuais sobre o papel de atuação destes conselheiros:

De fato, nesta realidade do Brasil já acima evidenciada, parece forçoso concluir que o papel central de atuação do Conselheiro Independente deve ser o de reduzir os beneficios privados do controle, através do monitoramento da administração da companhia e dos acionistas controladores, tendo em mente a relevância de sua ação, distinta da ação dos demais membros do Conselho de Administração, no sentido de garantir a proteção do público investidor, do interesse social(....). ${ }^{45}$

Esta autora, em sequência, argumenta que o conselheiro independente deve, portanto, primordialmente, ser desvinculado, não relacionado e/ou subordinado e livre de influências tanto do acionista controlador quanto da administração da companhia. E, naqueles casos em que não há um acionista controlador definido na companhia, não obstante serem raros no Brasil, o conselheiro independente deve monitorar a gestão dos administradores e mitigar os conflitos de representação, os conflitos de agência. ${ }^{46}$

\footnotetext{
${ }^{44}$ MUNHOZ, Eduardo Secchi. Desafios do Direito Societário Brasileiro na Disciplina da Companhia Aberta: Avaliação dos sistemas de controle diluido e concentrado. In: Direito Societário - Desafios Atuais. DE CASTRO, Rodrigo R. M.; ARAGÃO, Leandro Santos (Coord.). São Paulo: Quartier Latin. 2009. P.257.

${ }^{45}$ GELMAN, Marina Oehling. Op. cit. p. 72.

${ }^{46}$ GELMAN, Marina Oehling. Op. cit. p. 73.
} 
Adicionalmente à consonância com as posições expostas acima, deve ser ressaltado que a classificação dos conselheiros independentes como simples "conselheiros dos minoritários", comumente feita na prática forense e baseada no simples fato de tal conselheiro não possuir vínculos com o acionista controlador, deriva de uma análise muito rasa dos conceitos e funções atribuíveis ao conselheiro independente. Como aludido acima, mais do que meramente defender interesses minoritários, o conselheiro independente tem um compromisso principal com a companhia em si. O acionista minoritário possui mecanismos próprios para a eleição de seus representantes no conselho de administração, tais como o voto múltiplo, tratado no art. 141 da Lei das S.A., de forma que o conselheiro independente não é necessariamente um defensor direto de seus interesses, sendo, inclusive, comumente, eleito pelo próprio acionista controlador. Não se pode afastar o dever do conselheiro independente brasileiro de monitorar os abusos e benefícios privados do controle, que é intrínseco ao exercício de suas funções, porém, este conselheiro, acima de qualquer acionista, quer seja ele minoritário ou majoritário, tem como papel essencial agregar valor à companhia como um todo e garantir segurança ao público investidor e ao mercado de ações de maneira geral. Nota-se que o conselheiro independente tem atribuições muito mais amplas, abrangentes e primordiais do que simplesmente ser uma espécie de "justiceiro" dos minoritários contra abusos cometidos pelo controlador, ou então uma espécie de "inimigo" do acionista controlador. Neste sentido, o conselheiro é um sinal substancial de que a companhia que o nomeou adota sérios instrumentos de governança corporativa, o que garante a esta companhia grande credibilidade perante o mercado e faz com que seja objeto de maiores investimentos. Exercendo tal papel de maneira plena, o conselheiro independente atua na prática, sim, em benefício do acionista controlador, o que não pode ser confundido com em benefício exclusivo do acionista controlador. 


\section{CONSELHO DE ADMINISTRAÇÃO E GOVERNANÇA CORPORATIVA}

\subsection{O Conselho de Administração, e Competências e Funções dos Conselheiros}

O conselho de administração é o órgão administrativo que, dentro da estrutura das sociedades anônimas, se insere entre a assembleia geral e a diretoria. ${ }^{47} \mathrm{O}$ conselho de administração é obrigatório apenas para companhias abertas, das quais tratamos no presente trabalho, companhias de capital autorizado e de economia mista, como disposto nos artigos $138^{48}$ e $239^{49}$ da Lei das S.A.

As competências atribuídas ao conselho de administração estão previstas na Lei das S.A. e podem ser também definidas no estatuto social da companhia. Ao conselho de administração foram atribuídas as seguintes competências, nos termos do Art. 142 da Lei das S.A.:

"I - fixar a orientação geral dos negócios da companhia;

II - eleger e destituir os diretores da companhia e fixar-lhes as atribuições, observado o que a respeito dispuser o estatuto;

\footnotetext{
${ }^{47}$ ADAMEK, Marcelo Vieira Von. Responsabilidade Civil dos Administradores de S/A e as ações correlatas. São Paulo: Saraiva. 2009. p.21.

48 “Art. 138. A administração da companhia competirá, conforme dispuser o estatuto, ao conselho de administração e à diretoria, ou somente à diretoria.

$\S 1^{\circ} \mathrm{O}$ conselho de administração é órgão de deliberação colegiada, sendo a representação da companhia privativa dos diretores.

$\S 2^{\circ}$ As companhias abertas e as de capital autorizado terão, obrigatoriamente, conselho de administração."

49 “Art. 239. As companhias de economia mista terão obrigatoriamente Conselho de Administração, assegurado à minoria o direito de eleger um dos conselheiros, se maior número não lhes couber pelo processo de voto múltiplo.

Parágrafo único. Os deveres e responsabilidades dos administradores das companhias de economia mista são os mesmos dos administradores das companhias abertas."
} 
III - fiscalizar a gestão dos diretores, examinar, a qualquer tempo, os livros e papéis da companhia, solicitar informações sobre contratos celebrados ou em via de celebração, e quaisquer outros atos;

IV - convocar a assembleia-geral quando julgar conveniente, ou no caso do artigo 132 ;

$V$ - manifestar-se sobre o relatório da administração e as contas da diretoria;

$V I$ - manifestar-se previamente sobre atos ou contratos, quando o estatuto assim o exigir;

VII - deliberar, quando autorizado pelo estatuto, sobre a emissão de ações ou de bônus de subscrição;

VIII - autorizar, se o estatuto não dispuser em contrário, a alienação de bens do ativo não circulante, a constituição de ônus reais e a prestação de garantias a obrigações de terceiros;

IX - escolher e destituir os auditores independentes, se houver."

Em termos gerais, pode-se dizer que o conselho de administração foi criado para orientar os negócios da companhia, eleger os diretores e monitorar sua gestão. A diretoria, por sua vez, deve representar a companhia e praticar os atos necessários ao seu funcionamento regular, isto é, os atos corriqueiros, do "dia-a-dia" da companhia. ${ }^{50}$

Deve ser salientado ainda que, como a eleição dos membros do conselho de administração é feita pela Assembleia Geral, a maioria dos membros deste órgão é eleita pelo grupo de controle, observada a concentração de propriedade acionária brasileira e o princípio majoritário vigente. De qualquer forma, a qualquer conselheiro eleito, tenha ele sido escolhido por acionista minoritário ou majoritário, são imputados diversos deveres.

50 Lei das S.A. "Art. 144. No silêncio do estatuto e inexistindo deliberação do conselho de administração (artigo 142, n. II e parágrafo único), competirão a qualquer diretor a representação da companhia e a prática dos atos necessários ao seu funcionamento regular." 
Em resumo, a Lei das S.A. impõe aos conselheiros, independentes ou não, diversos deveres fiduciários, tais como: diligência (art. 153 da Lei das S.A. ${ }^{51}$ ), lealdade (artigo 155 da Lei das S.A. ${ }^{52}$ ), evitar situações de conflito de interesses (art. 156 da Lei das S.A. ${ }^{53}$ ) e informar (art. 157 da Lei das S.A. ${ }^{54}$ ). Vale menção à lição de VERÇOSA sobre o dever de lealdade, precioso ao presente ponto: "O dever de lealdade previsto no art. 155 da LSA predomina soberano sobre a relação de obediência que o conselheiro eleito por grupo de acionista pudesse ter em relação a estes (...)". ${ }^{55}$

Não obstante a existência de tais deveres, outra incumbência imputada aos conselheiros, de grande relevância ao presente trabalho, e que vem carregada de discussões pela sua redação subjetiva, é aquela prevista no $\S 1^{\circ}$ do artigo 154 da Lei das S.A.: o dever de independência, como definido pela doutrina.

O caput e o parágrafo primeiro do artigo 154 da Lei das S.A. determinam que:

Art. 154. O administrador deve exercer as atribuições que a lei e o estatuto lhe conferem para lograr os fins e no interesse da companhia, satisfeitas as exigências do bem público e da função social da empresa.

\footnotetext{
51 “Art. 153. O administrador da companhia deve empregar, no exercício de suas funções, o cuidado e diligência que todo homem ativo e probo costuma empregar na administração dos seus próprios negócios."

52 "Art. 155. O administrador deve servir com lealdade à companhia e manter reserva sobre os seus negócios, sendo-lhe vedado: (...)"

53 "Art. 156. É vedado ao administrador intervir em qualquer operação social em que tiver interesse conflitante com o da companhia, bem como na deliberação que a respeito tomarem os demais administradores, cumprindo-lhe cientificá-los do seu impedimento e fazer consignar, em ata de reunião do conselho de administração ou da diretoria, a natureza e extensão do seu interesse. (...)"

54 “Art. 157. O administrador de companhia aberta deve declarar, ao firmar o termo de posse, o número de ações, bônus de subscrição, opções de compra de ações e debêntures conversíveis em ações, de emissão da companhia e de sociedades controladas ou do mesmo grupo, de que seja titular.(...)"

55 VERÇOSA, Haroldo Malheiros Duclerc. Curso de direito comercial. v. 3. $2 a$ ed. São Paulo: Malheiros. 2010. p. 433.
} 
$\S 1^{\circ} \mathrm{O}$ administrador eleito por grupo ou classe de acionistas tem, para com a companhia, os mesmos deveres que os demais, não podendo, ainda que para defesa do interesse dos que o elegeram, faltar a esses deveres.

É claro, portanto, que o legislador outorgou ao membro do conselho de administração, bem como ao diretor, já que ambos em conjunto compõem a administração da companhia, um padrão de comportamento independente, ou seja, para atuarem de maneira isenta e profissional, voltado ao interesse da companhia em detrimento ao dos acionistas que o elegeram.

Todavia, cumpre-se também diferenciar o dever de independência previsto no texto do art. 154 supramencionado do conceito de conselheiro independente. Para tal, esclarece CEREZETTI que "a independência deve ser entendida como regra aplicável a todos os administradores, e não apenas àqueles qualificados como 'independentes'., „56

O dever legal de independência também é muito bem esclarecido por NOVAES FRANÇA nos seguintes termos:

A direção da empresa compete com exclusividade aos administradores, que por ela respondem e que - por mais esse motivo - não estão adstritos e obedecer a instruções, mesmo que do acionista controlador, a respeito de matéria da sua competência. Mais ainda. Não só não estão obrigados a seguir instruções como não podem fazê-lo, em face de seu dever de independência, que ressalta clara e explicitamente do disposto no art. 154 , e seu respectivo $\S 1^{\circ}$, da Lei 6.404/76. ${ }^{57}$

Vale ressaltar ainda, como já apontado por SILVA e CAMARGO ${ }^{58}$, que o escopo de atuação dos conselheiros independentes é idêntico ao dos demais membros do conselho de administração, já que não há regulação,

\footnotetext{
${ }^{56}$ CEREZETTI, Sheila Christina Neder. Op. Cit.. p. 589

${ }^{57}$ NOVAES FRANÇA, Erasmo Valadão Azevedo e. Dever de informar dos administradores de companhias abertas. Inexistência de submissão ao acionista controlador. São Paulo: Malheiros Editores. 2009. PP. 370-371.

${ }^{58}$ DA SILVA, Thiago José; DE CAMARGO, André Antunes Soares. Op. Cit. P. 62.
} 
autorregulação ou estatuto que, via de regra (já que, apesar de raro, nada impeça que estatutos confiram), funções específicas aos conselheiros independentes, diferentes daquelas atribuídas aos demais conselheiros.

\subsection{Porque 0 Conselho de Administração e 0 Conselheiro Independente se tornaram pilares da Governança Corporativa}

GORGON $^{59}$, em seu estudo sobre a evolução do papel do conselheiro independente americano, já apontava que, naquele país, ao longo do século XX, o conselho de administração teria evoluído de atividades de aconselhamento e sugestão na condução dos negócios para um papel de monitor das práticas da diretoria. ${ }^{60}$

Neste sentido, como já aludido anteriormente neste trabalho, o conselheiro independente passa a ser fundamental como mecanismo de mitigação de problemas de agência. Assim sendo, em um mundo contemporâneo de grande simetria de informações e direcionamento das corporações para maximização do patrimônio de investidores, o conselheiro independente aparece como aquele que não depende dos administradores internos da companhia, tendo mais liberdade para decidir e se preocupar exclusivamente com os acionistas.

A partir da diferenciação dos problemas de agência existentes em mercados dispersos e concentrados, já expostos acima, a figura do conselheiro independente se tornou, como bem apontado por GELMAN, portanto, em

\footnotetext{
59 GORDON, Jeffrey N. The rise of independent directors in the United States, 1950-2005: of shareholder value and 'stock market prices. Stanford Law Review, vol. 59. 2007. Disponível em: http://ssrn.com/abstract $=928100$.

${ }^{60}$ Ibidem. p. 9.
} 
(...) instrumento central no conselho de administração como prática de boa e adequada governança corporativa, tanto no ambiente disperso, quanto no ambiente concentrado, na medida em que é este que tem melhores condições de se colocar de forma independente, isenta, livre de influências pessoais, seja dos administradores, seja dos acionistas controladores, na busca pela maximização do valor da companhia. $^{61}$

${ }^{61}$ GELMAN, Marina Oehling. op cit. p. 32. 


\section{O CONSELHEIRO INDEPENDENTE}

Como introduzido nos capítulos anteriores, o tema envolvendo o conceito de conselheiro independente vem sendo objeto de atenção em diversos países, os quais, ao se debruçarem sobre essa questão, construíram conceitos de conselheiro independente que, apesar de possuírem bases comuns até certo ponto, são distintos entre si.

A observação introdutória de PARENTE, apesar de referente à realidade brasileira, é abrangente às demais definições existentes:

Como já salientado anteriormente, é preciso que o conselheiro de administração se torne ativo, efetivo, presente e sobretudo independente.

É também indispensável que as funções do conselho sejam tomadas com consciência profissional e observados parâmetros técnicos com vistas ao melhor retorno do investimento. Um bom conselho de administração valoriza o investimento.

Para tanto, é mister que haja uma evolução na cultura empresarial brasileira no sentido de que os indicados para exercer a função de conselheiro sejam profissionais independentes. Sabe-se que é difícil ao controlador abdicar de participar de conselhos de administração de suas próprias empresas, o que é perfeitamente compreensivel quando o controlador é o fundador da sociedade. (...). Portanto, é de todo inconveniente que o conselho de administração seja controlado por familiares ou amigos dos controladores. As indicações para o exercício das funções de membro do conselho de administração devem recair sobre pessoas independentes $e$ recrutadas no mercado por sua capacidade técnica e disponibilidade para se dedicar à companhia e não por vínculos familiares ou afetivos com os acionistas, quer controladores quer minoritários. ${ }^{62}$

Sendo assim, na sequência serão apresentados os conceitos vigentes no Brasil, quais sejam aqueles desenvolvidos pelo IBGC, pela CVM e pela BM\&FBOVESPA. Como contraposição aos conceitos brasileiros, serão dissecados os conceitos observados no exterior, mais especificamente nos Estados Unidos, e em países asiáticos e europeus. E, por fim, após a análise

\footnotetext{
${ }^{62}$ PARENTE, Norma. Principais Inovações introduzidas pela Lei $n^{\circ} 10.303$, de 31 de outubro de 2011, à Lei de Sociedades por Ações. In: LOBO, Jorge (coord.). Reforma da lei das sociedades anônimas: inovações e questões controversas da Lei n. 10.303/2001. Rio de Janeiro: Forense. 2002. p. 31 .
} 
dos diferentes conceitos existentes e do estabelecimento de certos vínculos com os temas já abordados acima, serão levantadas algumas questões controversas envolvendo o atual conceito vigente de conselheiro independente no País, de forma a fomentar a discussão se este cumpre, na prática, com os objetivos para os quais se propõe.

\subsection{Conceitos de Conselheiro Independente no Brasil.}

\subsubsection{O Conceito de Independente do IBGC}

O IBGC foi pioneiro no Brasil na formulação de sugestões de governança corporativa, quando, ainda no ano de 1999, lançou o primeiro código de práticas de governança corporativa do Brasil, denominado "Código Brasileiro de Melhores Práticas de Governança Corporativa". Neste, curiosamente, antes de qualquer previsão normativa neste sentido, já eram previstas questões de independência do Conselho de Administração e, considerando-se o fato do IBGC ter sido precursor desta temática no país, é razoável que tenha tido alguma influência nos conceitos criados posteriormente, inclusive nos regimentos dos segmentos especiais do Novo Mercado e Nível 2.

O Código do IBGC está atualmente em sua $4^{\mathrm{a}}$ edição ${ }^{63}$, a qual foi revisada em setembro de 2009 , e trata tanto da quantidade ideal de conselheiros independentes dentro do Conselho de Administração, quanto do conceito de independência em si.

O IBGC, consoante com a grande maioria dos códigos de boa governança mundiais, adota o método de listar as características que um

\footnotetext{
${ }^{63}$ Disponível em http://www.ibgc.org.br/userfiles/files/Codigo_Final_4a_Edicao.pdf.
} 
membro do conselho de administração não deve possuir para ser considerado independente, ao invés de apresentar uma definição propriamente dita. Sendo assim, o item 2.16 do Código do IBCG prevê:

"O conselheiro independente caracteriza-se por:

- Não ter qualquer vínculo com a organização, exceto participação não relevante no capital;

- Não ser sócio controlador, membro do grupo de controle ou de outro grupo com participação relevante, cônjuge ou parente até segundo grau destes, ou ligado a organizações relacionadas ao sócio controlador;

- Não estar vinculado por acordo de acionistas;

- Não ter sido empregado ou diretor da organização (ou de suas subsidiárias) há pelo menos, 3 (três) anos;

- Não ser ou ter sido, há menos de 3 (três) anos, conselheiro de organização controlada;

- Não estar fornecendo, comprando ou oferecendo (negociando), direta ou indiretamente, serviços elou produtos à organização em escala relevante para o conselheiro ou a organização;

- Não ser cônjuge ou parente até segundo grau de algum diretor ou gerente da organização;

- Não receber outra remuneração da organização, além dos honorários de conselheiro (dividendos oriundos de participação não relevante no capital estão excluídos desta restrição);

- Não ter sido sócio, nos últimos 3 (três) anos, de firma de auditoria que audite ou tenha auditado a organização neste mesmo período;

- Não ser membro de entidade sem-fins lucrativos que receba recursos financeiros significativos da organização ou de suas partes relacionadas;

- Manter-se independente em relação ao CEO;

- Não depender financeiramente da remuneração da organização."

Quanto à quantidade ideal de membros independentes dentro do conselho de administração, o IBGC preconiza:

A quantidade de conselheiros independentes no Conselho dependerá do grau de maturidade da organização, do seu ciclo de vida e de suas características. 
Recomenda-se que a maioria seja composta por independentes, contratados por meio de processos formais e com escopo de atuação e qualificação bem definido ${ }^{64}$

Por fim, o item 2.15 do Código do IBGC faz menção expressa, antes mesmo de iluminar o seu conceito de independência, à obrigação de responsabilidade imposta ao Conselheiro Independente com relação à companhia, e não ao acionista que o elegeu:

O conselheiro deve buscar a máxima independência possivel em relação ao sócio, ao grupo acionário ou à parte interessada que o tenha indicado ou eleito para o cargo e estar consciente de que, uma vez eleito, sua responsabilidade se refere à organização.

É elogiável que o IBGC tenha listado a necessidade do conselheiro independente não estar vinculado a acordo de acionistas, o que será tratado em maiores detalhes a seguir e é uma das principais causas da perda da efetiva independência do conselheiro. Todavia, é também notório que ao indicar que o conselheiro não deve ser "ligado" ao sócio controlador, o IBGC não definiu com fundamentos objetivos o que seria esta ligação, deixando este a critério dos acionistas o juízo de valor sobre esta relação. Considerando-se que quem predomina na eleição dos conselheiros é o acionista controlador e majoritário, é natural que este não tenha grande interesse em restringir o rol daqueles que por ele poderão ser eleitos. ${ }^{65}$

Além disso, também deve ser criticada a ausência de qualquer previsão do IBGC no tocante à possibilidade de destituição imotivada e a qualquer momento do conselheiro pelo acionista controlador que o elegeu, o que exerce uma pressão neste conselheiro que, por muitas vezes, também compromete a sua independência. Esta crítica também será esmiuçada abaixo.

\footnotetext{
${ }^{64}$ Item 2.16 do "Código Brasileiro de Melhores Práticas de Governança Corporativa.

${ }^{65}$ GELMAN, Marina Oehling. Op. cit. p. 113
} 
De qualquer forma, apesar das omissões supramencionadas, frisa-se que o conceito apresentado pelo IBGC, apesar de se tratar de mera recomendação, não havendo qualquer coerção ou obrigatoriedade para sua adoção, vai além da definição vigente nos regulamentos da BM\&FBOVESPA, detalhada em sequência.

\subsubsection{O Conceito de Independente da CVM}

Registre-se que a Comissão de Valores Mobiliários, no exercício da sua função legal de regulamentar, desenvolver, controlar e fiscalizar o mercado de valores mobiliários do país, nunca tenha apresentado um conceito formal de conselheiro independente, mas apenas indicações ou menções genéricas.

Neste sentido, em sua "Cartilha de Recomendações da CVM Sobre Governança Corporativa", publicada em 2002 e meramente composta de recomendações, a CVM prevê que:

“(...)O conselho de administração deve ter de cinco a nove membros tecnicamente qualificados, com pelo menos dois membros com experiência em finanças $e$ responsabilidade de acompanhar mais detalhadamente as práticas contábeis adotadas. $O$ conselho deve ter o maior número possível de membros independentes da administração da companhia. Para companhias com controle compartilhado, pode se justificar um número superior a nove membros. O mandato de todos os conselheiros deve ser unificado, com prazo de gestão de um ano, permitida a reeleição". 66

Posteriormente, no ano de 2008, a CVM emitiu o Parecer de Orientação $\mathrm{CVM} \mathrm{n}^{0} 35$, com a motivação explícita de dar uma aplicação mais concreta e objetiva aos deveres fiduciários atribuídos aos membros do Conselho de Administração pela Lei das S.A., no sentido de agir no interesse da companhia e de todos os seus acionistas, principalmente em operações envolvendo

\footnotetext{
${ }^{66}$ Cartilha de Recomendações da CVM Sobre Governança Corporativa. 2002. Disponível em http://www.cvm.gov.br/port/publ/cartilha.doc.
} 
incorporação de ações envolvendo empresas controladoras e controladas. ${ }^{67}$ Neste parecer, declarando pautar-se em experiência internacional relativa à interpretação dos deveres fiduciários dos administradores, a CVM recomendou, no item 3 do parecer:

"Além disso, seguindo a experiência internacional acerca da interpretação dos deveres fiduciários dos administradores, a CVM recomenda que:

i) um comitê especial independente seja constituido para negociar a operação e submeter suas recomendações ao conselho de administração, observando as orientações contidas no parágrafo anterior; ou

ii) a operação seja condicionada à aprovação da maioria dos acionistas nãocontroladores, inclusive os titulares de ações sem direito a voto ou com voto restrito."

Relevante ao presente estudo é o conceito do denominado "comitê especial independente", para o qual a CVM adotou a seguinte premissa, literalmente extraída do Parecer CVM 35:

A independência dos membros do comitê especial não pode ser determinada de antemão, devendo ser examinada a cada caso.

De qualquer modo, a CVM presumirá a independência, salvo demonstração em contrário, de pessoas que atendam à definição de "conselheiro independente" prevista no Regulamento do Novo Mercado da Bolsa de Valores de São Paulo.

É notável que a referência feita pela CVM à definição de Conselheiro Independente é claramente emprestada do conceito elaborado BM\&FBOVESPA e abaixo definido. Todavia, ao indicar de antemão que esta referência depende de não haver prova em contrário, reconhece simultaneamente a fragilidade da definição vigente nos regulamentos do Novo Mercado e do Nível 2 da BM\&FBOVESPA, que dependeria de uma análise casuística. GELMAN defende que, neste caso que:

67 Disponível em: http://www.cvm.gov.br/export/sites/cvm/legislacao/pare/anexos/pare035.pdf. Acessado em 19/09/2015. 
(...) a falta de regulação do assunto, também pela CVM, faz com que o juízo sobre sua forma de agir continue nas mãos do próprio agente, isto é, do próprio membro do Conselho. Eventual desvio de conduta independente dependerá de questionamento e comprovação por terceiros. ${ }^{68}$

Portanto, resta claro que tampouco a CVM contribuiu efetivamente com o mercado de capitais ao abster de se posicionar de maneira definitiva com relação ao conceito de independência do conselheiro, adotando parcialmente e de forma frágil as definições da BM\&FBOVESPA. Espera-se que a CVM ainda se manifeste a respeito, colaborando com a presente discussão e prestando serviços proveitosos ao mercado acionário, como é de seu costume.

\subsubsection{O Conceito de Independente na BM\&FBOVESPA}

A despeito das recomendações do Código do IBGC e das abordagens feitas pela CVM no Parecer CVM 35 e na Cartilha CVM, a única definição vigente de conselheiro independente que é, de fato, obrigatória a companhias, é aquela definição exposta nos regulamentos dos segmentos especiais Novo Mercado e Nível 2 da BM\&FBOVESPA. Vale ressaltar que a adesão às regras de ambos os segmentos é voluntária, não há qualquer obrigatoriedade para uma companhia acolher tais regras e listar-se nestes segmentos. No entanto, assim que uma companhia decide ter suas ações negociadas através destes segmentos, os respectivos regulamentos e suas regras, incluindo a eleição de conselheiros independentes, de acordo com o conceito ali apresentado, tornamse obrigatórias.

A definição de Conselheiro Independente foi introduzida pela BM\&FBOVESPA nos regulamentos do Novo Mercado e do Nível 2 no ano de 2006, e encontra-se presente tanto no "Regulamento de Listagem do Novo

${ }^{68}$ GELMAN, Marina Oehling. Op. cit. p. 116 
Mercado",69, quanto no "Regulamento de Práticas Diferenciadas de Governança Corporativa Nível 2,70, no item 2.1 de termos definidos de ambos os regulamentos, e segue a mesma linha adotada pelo IBGC, de indicar todas as características excludentes que um conselheiro não pode ter, para que seja considerado independente. Novamente, ressalta-se que tal conceito é o único que pode ser considerado como integrante do sistema normativo brasileiro, mesmo que no campo da auto regulação, o que por si só já demonstra a maior importância que a este deve ser atribuído em comparação com as demais previsões brasileiras sobre o tema e acima discorridas. Tal definição, portanto, é a que segue:

\begin{abstract}
"Conselheiro Independente" caracteriza-se por:
(i) não ter qualquer vínculo com a Companhia, exceto participação de capital;

(ii) não ser Acionista Controlador, cônjuge ou parente até segundo grau daquele, ou não ser ou não ter sido, nos últimos 3 anos, vinculado a sociedade ou entidade relacionada ao Acionista Controlador (pessoas vinculadas a instituições públicas de ensino elou pesquisa estão excluidas desta restrição);
\end{abstract}

(iii) não ter sido, nos últimos 3 anos, empregado ou diretor da Companhia, do Acionista Controlador ou de sociedade controlada pela Companhia;

(iv) não ser fornecedor ou comprador, direto ou indireto, de serviços elou produtos da Companhia, em magnitude que implique perda de independência;

(v) não ser funcionário ou administrador de sociedade ou entidade que esteja oferecendo ou demandando serviços elou produtos à Companhia;

(vi) não ser cônjuge ou parente até segundo grau de algum administrador da Companhia;

(vii) não receber outra remuneração da Companhia além da de conselheiro (proventos em dinheiro oriundos de participação no capital estão excluídos desta restrição)."

69 Disponível em http://www.bmfbovespa.com.br/Pdf/RegulamentoNMercado.pdf. Acessado em 20/09/2015.

${ }^{70}$ Disponível em: http://www.bmfbovespa.com.br/Pdf/Folder_Nivel2.pdf. Acessado em 20/09/2015. 
Para que o conceito de Conselheiro Independente seja claro, resta pertinente também apresentar os conceitos da BM\&FBOVESPA nos regulamentos supramencionados para acionista controlador e poder de controle, quais sejam:

"Acionista Controlador" significa o acionista ou o grupo de acionistas vinculado por acordo de acionistas ou sob controle comum que exerça o Poder de Controle da Companhia.";

e

"Poder de Controle" significa o poder efetivamente utilizado de dirigir as atividades sociais e orientar o funcionamento dos órgãos da Companhia, de forma direta ou indireta, de fato ou de direito. Há presunção relativa de titularidade do controle em relação à pessoa ou ao grupo de pessoas vinculado por acordo de acionistas ou sob controle comum ("grupo de controle") que seja titular de ações que lhe tenham assegurado a maioria absoluta dos votos dos acionistas presentes nas três últimas assembleias gerais da Companhia, ainda que não seja titular das ações que the assegurem a maioria absoluta do capital votante.

Em vista da importância do conceito de conselheiro independente apresentado acima para o tema do presente, a seguir serão apontados, dentre os itens acima listados, alguns pontos específicos que podem ser considerados problemáticos ou dúbios, principalmente aqueles indicados por GELMAN. ${ }^{71}$

Quanto ao item (i) do conceito de Conselheiro Independente da BM\&FBOVESPA, destaca-se o fato de que sua redação prevê que a condição de acionista não descaracteriza a independência do conselheiro. Além disso, deve ser feita a ressalva de que não há um esclarecimento objetivo quanto ao que pode ser considerado "vínculo" com a companhia ou com entidade relacionada ao acionista controlador. A subjetividade desta expressão enseja diversas interpretações, tais como a de que a vinculação a acordo de acionistas de controle não seria considerado um vínculo com a companhia. Novamente, a

\footnotetext{
${ }^{71}$ GELMAN, Marina Oehling. Op. cit. pp. 118-129
} 
relação dos conselheiros independentes aos acordos de controle, seus detalhes e contornos estão aprofundados infra, em sub-capítulo próprio.

Pode também ser feita uma crítica ao item (ii) do conceito supramencionado, o qual, ao acertadamente afastar o conselheiro independente do acionista controlador, alarga tal afastamento apenas aos cônjuges e parentes até segundo grau deste acionista controlador, sem, contanto, abranger a pessoa com quem se viva em união estável ou pessoas vivendo na mesma residência do acionista controlador. Como bem defendido por GELMAN, portanto, tais pessoas, além de tios e primos do acionista controlador, não estão incluídos nesta limitação, apesar de possuírem, normalmente, vínculo de interesse equivalente àquele do cônjuge ou parente de segundo grau. Esta avaliação pode, ainda, ser estendida ao item (vi) do conceito de conselheiro independente, que também veda o conselheiro independente de ser cônjuge ou parente até segundo grau de algum administrador. Caso esta vedação fosse vedada também a companheiros, pessoas com quem se viva em união estável e com quem se viva na mesma residência, bem como parentes de terceiro grau, pelas mesmas razões, esta limitação ao conselheiro independente poderia surtir efeitos práticos mais eficientes.

Vale mencionar ainda que, de maneira geral, no conceito apresentado, não são classificadas como conflituosas e excludentes da independência do conselheiro relações de emprego ou societárias entre o conselheiro e sociedades relacionadas ao acionista controlador e/ou à companhia. No entanto, não fazer menção a empresas do mesmo conglomerado econômico da companhia ou do acionista controlador como máculas à independência do conselheiro parece contrário e destoante à lógica de afastamento da independência em relações de emprego adotada para sociedade controlada pela companhia. 


\subsection{Conceitos de Conselheiro Independente no Direito Comparado}

Uma vez apresentados acima os conceitos existentes no Brasil, bem como o papel que deve ser exercido pelo conselheiro independente no país, resta serem expostos alguns conceitos estrangeiros, comparando-os com os nacionais, para que sejam verificados seus pontos convergentes e divergentes.

Neste sentido, serão analisados na sequência alguns conceitos vigentes nos Estados Unidos, dado o destaque deste país no mercado de capitais e o seu pioneirismo na introdução do conceito de conselheiro independente. Também será explorado o conceito vigente na China, país que, ao lado do Brasil (além de Índia, Rússia e África do Sul), forma o BRICS, grupo político de cooperação formado por países emergentes e que, até certo ponto, pode ser considerados competidor do Brasil na atração de recursos estrangeiros. Por fim, serão apresentados conceitos vigorantes na Europa, especificamente na Alemanha e Portugal, respectivamente, devido à liderança política e econômica exercida neste continente, e à proximidade cultural e histórica com o Brasil. Todos esses conceitos estrangeiros apresentados, por motivos lógicos, não são redigidos em português (à exceção do exemplo luso exposto), mas em inglês. Não obstante, todos estarão livremente traduzidos ao português neste trabalho, para uma melhor compreensão de seus respectivos conteúdos.

\subsubsection{CaIPERS}

Como visto anteriormente neste trabalho, a CalPERS - California Public Emplopyees' Retirement System teve participação especial na história das práticas de governança corporativa nos Estados Unidos. Portanto, é de valor e interesse ao presente estudo o que a CalPERS define como conselheiro 
independente em seu "Global Principles of Accountable Corporate

Governance” (GPACG), o seu guia de melhores práticas, que foi atualizado pela última vez em março de $2015^{72}$.

Nessa linha, o GPACG trata da definição do conselheiro independente nos seus Anexos A e E. Neste sentido, no Anexo A, abaixo traduzido, o GPACG adota as sugestões do Council of Institutional Investors, apresentando primeiramente um conceito genérico, para, posteriormente, indicar uma lista detalhada daqueles que não devem ser considerados conselheiros independentes. As previsões do Anexo A estão abaixo traduzidas nos seguintes termos:

"7.2239 Definição Básica de um Conselheiro Independente: Um conselheiro independente é alguém cuja única conexão profissional não trivial, familiar ou financeira com a companhia, o Presidente de seu Conselho de Administração, o Presidente da sua Diretoria ou qualquer outro Diretor é seu mandato de membro do Conselho de Administração. Colocado de forma mais simples, um conselheiro independente é a pessoa cujo mandato constitui sua única ligação com a companhia.

7.3240 Instruções para Identificação da Independência de um Conselheiro: as notas que seguem são fornecidas para dar maior clareza e direcionamento na interpretação das relações especificadas. Um Conselheiro não será considerado independente se ele ou ela:

$7.3 a$ É, ou foi nos últimos 5 anos, ou tem um parente que é, ou foi nos últimos 5 anos, empregado da companhia ou empregado de/por um Conselheiro da companhia ou de uma pessoa afiliada;

NOTA: uma relação de "pessoa afiliada" se estabelece se uma entidade, por si só ou através de arranjos com uma ou mais pessoas, detém ou possui poder de voto superior a 20\% do capital em outra pessoa, a menos que outra pessoa, por si só ou através de arranjos com uma ou mais pessoas, detém ou possui poder de voto em percentagem superior do capital desta outra pessoa. Para tal fim, sócios em jointventures e sócios em geral atendem a definição de pessoa afiliada, e diretores e empregados de joint-ventures e sociedades em geral são considerados pessoas afiliadas. Uma subsidiária será uma pessoa afiliada se pelos menos $20 \%$ de seu capital for detido pela companhia. Pessoas afiliadas incluem sociedades antecessora. Uma "antecessora" é uma sociedade que, durante os últimos 5 anos, foi parte de uma "fusão de iguais" com a companhia ou que representou mais de 50\% das vendas ou ativos da companhia quando essa antecessora tiver se tornado parte

72 Disponível em: https://www.calpers.ca.gov/docs/forms-publications/global-principles-corporategovernance.pdf. Acessado em 25/09/2015. 
da companhia. "Parentes" inclui cônjuge, pais, filhos, enteados, irmãos, sogros, genros e noras, cunhados, tios, sobrinhos e primos e qualquer pessoa que compartilhe a residência do Conselheiro.

$7.3 b$ É, ou foi nos últimos 5 anos, ou possui um parente que é, ou foi nos últimos 5 anos, um empregado, Conselheiro, ou detentor de mais de $20 \%$ de uma sociedade que seja um consultor remunerado da companhia ou de suas afiliadas, ou que receba remuneração de pelo menos \$50,000 por ser um consultor remunerado de um membro da Diretoria da companhia;

NOTA: Consultores incluem, mas não se limitam a, escritórios de advocacia, auditores, contadores, companhias de seguro e bancos comerciais ou de investimento. Para fins desta definição, um indivíduo servindo a uma sociedade como "terceiro" será considerado um empregado desta sociedade. O termo "membro da Diretoria" inclui o Presidente, o Diretor Industrial, o Diretor Financeiro, o Diretor Jurídico e o Diretor de Contabilidade de uma companhia. Isso inclui o presidente, tesoureiro, secretária, controller ou qualquer vice-presidente que esteja no comando principal de uma unidade de negócio, divisão ou departamento (tais como vendas, administrativo ou financeiro) ou desempenhe uma função de definição de políticas da companhia.

$7.3 c$ É, ou foi nos últimos cinco anos, ou possui um parente que é, ou foi nos últimos cinco anos, empregado ou detentor de $5 \%$ ou mais de participação societária em uma terceira sociedade que realize ou receba pagamentos da companhia de forma que: (i) tais pagamentos representem 1\% da receita bruta consolidada da terceira sociedade ou da companhia dentro de um ano fiscal; ou (ii) se a terceira sociedade for um devedor ou credor da companhia e o montante devido exceder 1\% do ativo da terceira sociedade ou da companhia. Participação societária significa propriedade registrada ou do beneficiário e não propriedade custodiada;

7.3d Recebeu ou pagou, nos últimos 5 anos, ou é parente de quem tenha pago ou recebido nos últimos 5 anos, mais de \$50,000 por conta de um contrato individual com a companhia, com um de seus Diretores ou com qualquer de suas afiliadas;

NOTA: Os membros do CII acreditam que mesmo pequenos contratos individuais, independentemente de sua formulação, podem ameaçar a completa independência de um Conselheiro. Isso inclui qualquer arranjo em que o Conselheiro tome ou conceda empréstimos em dinheiro à companhia em condições melhores (para o Conselheiro) do que aquelas disponíveis a público em geral - mesmo que nenhum outro serviço do Conselheiro seja especificado em conexão com esta relação,

7.3e É, ou foi nos últimos 5 anos, ou possui um parente que é, ou foi nos últimos 5 anos, empregado ou Conselheiro de uma fundação, universidade ou outra organização sem fins lucrativos que receba doações significativas da companhia, de qualquer de suas afiliadas ou de seu(s) Diretor(es) que tenha(m) sido beneficiário(a) direto(a) de qualquer doação feita a tais organizações; NOTA: Uma "doação significativa" é o menor valor entre $\$ 100,000$ ou $1 \%$ do total anual de doações recebidas pela organização;

7.3f É, ou foi nos últimos 5 anos, ou possui um parente que é, ou foi nos últimos 5 anos, membro de um Conselho inter-relacionado cujo Presidente da Diretoria ou outro empregado da companhia atue como membro do Conselho de uma terceira 
empresa (com ou sem fins lucrativos) que empregue o Conselheiro ou seu respectivo parente;

$7.3 \mathrm{~g}$ Tem um parente que é, ou foi nos últimos 5 anos, empregado, Conselheiro ou detentor de 5\% ou mais de uma terceira sociedade que seja um concorrente significativo da companhia; ou

7.3h É parte de um fundo fiduciário, contrato ou procuração que lhe conceda poderes de decisão como um administrador, a menos que for feita ampla divulgação e acordos de voto delimitados tais como os que são costumeiramente estabelecidos entre investidores e administradores em relação ao assento no Conselho de Administração ocupado pelo investidor."

\section{Como aludido, em um segundo momento, em seu Anexo E, o GPACG} apresenta outro conceito para o conselheiro independente, conforme segue:

"Anexo B241: "Conselheiro Independente" significa um Conselheiro que:

- Não é atualmente, e não foi nos últimos 5 anos, contratado pela Companhia para ocupação de cargo executivo;

- Não recebeu mais do que \$50,000 a título de remuneração direta pela Companhia durante qualquer período de 12 meses nos últimos 3 anos que não sejam:

i. honorários de Conselheiro ou membro de comitês incluindo reembolsos por despesas incorridas legitimamente; ou companhia.

ii. Pagamentos originados exclusivamente pelo investimento de capital na

- Não é afiliado a uma empresa que seja consultora da Companhia ou membro da alta gestão da Companhia durante qualquer período de 12 meses nos últimos 3 anos que tenha recebido mais do que \$50,000 da Companhia.

- Não é empregado de uma sociedade (cliente ou fornecedora) que tenha feito pagamentos a, ou recebido pagamentos da Companhia que excedam $\$ 200,000$ ou $2 \%$ da receita bruta consolidada da referida sociedade.

- Não é afiliado a uma organização sem fins lucrativos (incluindo associações de caridade) que receba contribuições da Companhia que excedam $\$ 200,000$ ou $2 \%$ da receita bruta consolidada da referida organização naquele ano.

- Não é parte de Conselhos inter-relacionados em que o Presidente da Diretoria ou outro empregado da Companhia ocupe cargo no Conselho de Administração de outro companhia que empregue o Conselheiro.

- Não tenha tido quaisquer das relações descritas nos itens acima com qualquer empresa relacionada ou subsidiária da Companhia.

- Não é um membro da família imediata de qualquer pessoa descrita neste Anexo E." 
Depreende-se dos conceitos acima, em primeiro lugar, em comparação com as definições pátrias, que a CalPERS apresenta detalhes, números e excludentes de forma muito mais minuciosa e precisa. Outra observação importante, relativa ao mercado pulverizado daquele país, é de que em nenhum momento é mencionada a figura do acionista controlador, já que o foco desta definição é evitar relações entre o conselheiro que se pretende que possa exercer sua função de forma independente e a própria companhia e seus diretores.

\subsubsection{NYSE}

Pela relevância da NYSE, como maior bolsa de valores do mundo em quantidade de companhias e em valor de mercado, bem como pela tradição da figura do conselheiro independente no mercado americano, é mister a importância da definição por esta apresentada para o conselheiro independente.

Neste sentido, a NYSE, em seu "Listed Company Manual", define conselheiro independente através do que denomina de "teste de independência" do seu item 302A.02, nos seguintes termos:

"A fim de restringir a definição de Conselheiro Independente para os fins desses parâmetros: (a) nenhum Conselheiro se qualificará como independente a menos que o Conselho de Administração afirme que referido Conselheiro não tem nenhuma relação material com a Companhia listada (seja diretamente ou como quotista, acionista ou Diretor de uma organização que tenha relações com a Companhia). Comentário: Não é possivel antecipar ou explicitamente prever todas as circunstâncias que podem indicar potenciais conflitos de interesse, ou que possam impactar na materialidade da relação de um diretor de uma companhia listada (referências a "companhia listada" inclui qualquer sociedade relacionada ou subsidiária de um grupo consolidado do qual a companhia listada faça parte). Assim, é melhor que os Conselhos que fazem determinações amplas de "independência" considerem todos os fatos e circunstâncias relevantes. Em especial,

\footnotetext{
${ }^{73}$ Disponível em: http://nysemanual.nyse.com/LCM/Sections/.
} 
ao analisar a materialidade da relação do Conselheiro com a companhia listada, o Conselho deve considerar a questão não apenas do ponto de vista do Conselheiro, mas também do ponto de vista de pessoas ou organizações com as quais o Conselheiro é afiliado. Relações materiais podem incluir relação comercial, bancária, industrial, consultoria, jurídica, contabilidade, relações de caridade e familiar, entre outros. No entanto, como a preocupação é a independência da Diretoria, a NYSE não vê a propriedade acionária, mesmo que de uma quantidade significativa de ações, por si só, como um impedimento para a independência. Exigência de Divulgação: A companhia listada deve cumprir os requisitos de divulgação estabelecidos no artigo 407 (a) do Regulamento SK.

(B) Além disso, um Conselheiro não é independente se:

(I) O Conselheiro é, ou foi nos últimos três anos, empregado da companhia, ou um membro imediato da familia é, ou foi nos últimos três anos, Diretor da empresa listada. Comentário: Emprego como Presidente Interino do Conselho ou da Diretoria ou outro cargo de Diretor não deve desqualificar um Conselheiro de ser considerado independente após esse emprego.

(II) O Conselheiro recebeu, ou tem um membro imediato da familia que tenha recebido, durante qualquer periodo de doze meses nos últimos três anos, mais de US \$120.000 em compensação direta da companhia, com exceção de honorários de Conselheiro ou de membro de comitês e pensões ou outras formas de compensação por serviço prestados anteriormente (desde que tal compensação não dependa de qualquer forma de serviço continuado). Comentário: A remuneração recebida por um Conselheiro por exercício do cargo de Presidente Interino do Conselho ou da Diretoria ou outro cargo de Diretor não precisa ser considerada na determinação da independência sob este aspecto. A remuneração recebida por um membro imediato da família para prestar serviço como um empregado da companhia (que não seja como um Diretor) não precisam ser considerados na determinação da independência sob este aspecto.

(III) (A) O Conselheiro é sócio ou empregado de uma empresa que é auditora interna ou externa da companhia; (B) o Conselheiro tem um familiar próximo que é sócio de uma empresa deste tipo, (C) o Conselheiro tem um familiar próximo que é empregado de uma empresa deste tipo e, pessoalmente, trabalha com auditoria da companhia, ou (D) o Conselheiro ou um familiar próximo foi, nos últimos três anos, sócio ou empregado de uma empresa deste tipo e pessoalmente trabalhou na auditoria da companhia dentro desse prazo.

(IV) O Conselheiro ou um familiar próximo é, ou foi nos últimos três anos, Diretor de outra empresa, na qual algum Diretor da Companhia participa do comitê de remuneração da empresa.

(V) O Conselheiro é empregado, ou um familiar próximo é Diretor, de uma empresa que fez pagamentos, ou recebeu pagamentos da companhia por propriedade ou serviços em um montante que, em qualquer dos últimos três anos fiscais, excedeu o maior valor entre de US $\$ 1$ milhão ou $2 \%$ da receita bruta consolidada desta empresa. Comentário: Ao aplicar o previsto nesta Seção 303 A.02 (b)(v), tanto os pagamentos quanto as receitas brutas consolidadas a serem medidos são aqueles declarados no último ano fiscal da outra empresa. Para os fins deste item considera- 
se somente a relação financeira entre a companhia e a empresa na qual o Conselheiro seja empregado atualmente, ou um familiar próximo seu seja Diretor atualmente; uma companhia não precisa considerar relações anteriores de emprego do Conselheiro ou o exercício do cargo de Diretoria de um familiar próximo seu no passado.

Requisito de divulgação: Contribuições para organizações isentas de impostos não devem ser consideradas para fins de pagamento da Seção 303 A.02 (b) (v), desde que, porém, a companhia divulgue, no ou através do seu site ou na suas demonstrações financeiras anuais, ou se a companhia não apresenta demonstrações financeiras anuais, no relatório anual da companhia no Formulário 10-K arquivado junto à SEC, tais contribuições feitas pela companhia a qualquer organização isenta de impostos em que qualquer Conselheiro Independente sirva como Diretor se, nos últimos três anos, as contribuições em um único ano fiscal da companhia para a organização excederem o maior valor entre US\$ 1 milhão ou $2 \%$ da receita bruta consolidada de tal organização isenta. Se esta divulgação for feita em ou através do site da companhia, a companhia deve divulgar esse fato na sua declaração anual ou relatório anual, conforme o caso, e fornecer o endereço do site. Os Conselhos de Administração de companhias são lembrados das suas obrigações de considerar a relevância de qualquer relacionamento, em conformidade com a Seção 303 A.02 (a) acima.

Comentário Geral a Seção 303 A.02 (b): Um "familiar próximo" inclui cônjuge, pais, filhos, irmãos, sogras e sogros, genros e noras, cunhados e cunhadas, e qualquer um (exceto empregados domésticos) que compartilhe a casa dessa pessoa. Ao aplicar as disposições desta Seção 303 A.02 (b), as companhias não precisam considerar os indivíduos que não são mais familiares próximos como resultado de separação judicial ou divórcio, ou aqueles que morreram ou ficaram incapacitado.

Adicionalmente, as referências a "companhias" ou "empresa" incluem qualquer sociedade relacionada ou subsidiária de um grupo consolidado do qual faça parte a companhia ou a referida outra empresa, conforme seja relevante para qualquer indicação dos padrões de independência estabelecidos nesta Seção 303A. 02 ( b)."

Resta claro, portanto, que a definição da NYSE segue os mesmos moldes da definição elaborada pela CalPERS e acima exposta. Ao contrário do IBGC, a NYSE estabelece como conflituosa a relação com aquela pessoa que vive sob o mesmo teto. Todavia, é nítido também que a NYSE é ainda menos preocupada no que concerne os acionistas controladores ao declarar, na letra A do item 303.A2: "No entanto, como a preocupação é a independência da Diretoria, a NYSE não vê a propriedade acionária, mesmo que de uma quantidade significativa de ações, por si só, como um impedimento para a independência." 
Assim sendo, para que as previsões da NYSE relativas à desconsideração do exercício independente do conselheiro possam ser aproveitadas em nível comparativo, estas precisam ser analisadas de forma estendida para a figura do acionista controlador. Apenas desta forma seria possível atender o objetivo do que se necessita, em terras nacionais, como o papel a ser desempenhado pelo conselheiro independente.

\subsubsection{China}

A China, como segunda maior economia mundial, também possui, assim como Brasil, majoritariamente companhias com estrutura concentrada. Vale mencionar, todavia, por ser uma república comunista, tais são em grande parte controlada pelo Estado

A definição mais recente e vigente de conselheiro independente no sistema normativo chinês é a do "Provisional Code of Corporate Governance of Securities Company" "74, que assim prevê

\footnotetext{
"Seção 3 Conselheiro Independente

Artigo 39 Companhias abertas devem introduzir Conselheiros Independentes em seus Conselhos de Administração de acordo com as regras da CSRC. O Conselheiro Independente deve ter conhecimentos básicos do mercado de capitais e deve estar familiarizado com as leis e regulamentos relevantes. Ele deve ser honesto e confiável e ter mais de 5 anos de experiência em ramos relacionados.

A pessoa em qualquer das circunstancias seguintes não devera ocupar a posição de Conselheiro Independente:

1. A pessoa que ocupe uma posição na companhia ou em suas partes afiliadas e parentes lineares e pessoas com relações sociais relevantes com referida pessoa.
}

\footnotetext{
${ }^{74}$ Disponível em: http://www.ecgi.org/codes/documents/provisional_cgcode_csrc.pdf. Acessado em $05 / 10 / 2015$
} 
2. A pessoa que ocupe uma posição em qualquer acionista que detenha ou controle mais de 5\% do capital da companhia ou ocupe uma posição em qualquer dos 5 principais acionistas e parentes lineares e pessoas com relações sociais relevantes com referida pessoa.

3. A pessoa que é acionista detentor ou controlador de mais de 5\% do capital da companhia e os parentes lineares e pessoas com relações sociais relevantes com referida pessoa.

4. A pessoa que fornece serviços financeiros, jurídicos e consultoria para a companhia e parentes lineares e pessoas com relações sociais relevantes com referida pessoa.

5. A pessoa que atende as circunstâncias listadas nos 4 itens anteriores no ano anterior.

6. A pessoa que assume o cargo de Conselheiro em outra companhia.

7. Outras pessoas especificadas no estatuto social.

Percebe-se da redação acima que a definição vigente na China apresenta-se como uma das mais restritivas vistas. Interessante notar como é desqualificado como independente o acionista detentor de $5 \%$ ou mais do capital social, bem como pessoas que ocupem uma posição na companhia, ou, ainda, pessoas que ocupem uma posição nos 5 principais acionistas da companhia, independentemente do percentual de participação, o que não tinha sido visto até agora. Também são desqualificadas pessoas que tenham relações sociais com aqueles considerados não independentes, o que, mesmo que de forma subjetiva, é um aspecto presente apenas no conceito chinês, dentre os analisados. 


\subsubsection{Portugal}

Em Portugal, país de óbvias e riquíssimas relações culturais, sociais e históricas com o Brasil, são apresentados conceitos de conselheiro independente em dois diferentes documentos, o "Código de Governo das Sociedades"75, do Instituto Português de Corporate Governance, e o "Código de Governo das Sociedades da CMVM" "76, da Comissão do Mercado de Valores Mobiliários portuguesa. Ambos, todavia, fazem uma conceituação muito semelhante, como visto abaixo, sendo a primeira definição aquela feita pelo Instituto Português de Corporate Governance e a segunda da Comissão do Mercado de Valores Mobiliários:

IV.3 Cada sociedade deve incluir um número adequado de administradores não executivos que cumpram os requisitos legislativos de independência, calculado em função da respectiva dimensão e da percentagem de dispersão accionista.

Para efeitos desta recomendação, considera-se independente a pessoa que não esteja associada a qualquer grupo de interesses especificos na sociedade nem se encontre em alguma circunstância suscetivel de afetar a sua isenção de análise ou de decisão, nomeadamente em virtude de:

(i) Ter sido colaborador da sociedade ou de sociedade que com ela se encontre em relação de domínio ou de grupo nos últimos três anos;

(ii) Ter, nos últimos três anos, prestado serviços ou estabelecido relação comercial significativa com a sociedade ou com sociedade que com esta se encontre em relação de domínio ou de grupo, seja de forma direta ou enquanto sócio, administrador, gerente ou dirigente de pessoa coletiva;

(iii) Ser beneficiário de remuneração paga pela sociedade ou por sociedade que com ela se encontre em relação de domínio ou de grupo além da remuneração decorrente do exercício das funções de administrador;

(iv) Viver em união de facto ou ser cônjuge, parente ou afim na linha reta e até ao $3 .^{\circ}$ grau, inclusive, na linha colateral, de administradores ou de pessoas singulares titulares direta ou indiretamente de participação qualificada;

\footnotetext{
${ }^{75}$ Disponível em:

http://www.cgov.pt/images/stories/ficheiros/codigo_de_governo_das_sociedades_do_ipcg.pdf . Acessado em 05/10/2015.

${ }^{76}$ Disponível em: http://www.cgov.pt/images/stories/ficheiros/4._novo_cd._gov._soc._cmvm.pdf . Acessado em 05/10/2015.
} 
(v) Ser titular de participação qualificada ou representante de um accionista titular de participações qualificadas.

\section{E, ainda,}

II.1.4. Entre os administradores não executivos deve contar-se um número adequado de administradores independentes, tendo em conta a dimensão da sociedade e a sua estrutura acionista, que não pode em caso algum ser inferior a um quarto do número total de administradores.

Entre os administradores não executivos deve contar-se um número adequado de administradores independentes, tendo em conta a dimensão da sociedade e a sua estrutura acionista, que não pode em caso algum ser inferior a um quarto do número total de administradores.

Considera-se independente a pessoa que não esteja associada a qualquer grupo de interesses específicos na sociedade nem se encontre em alguma circunstância suscetivel de afetar a sua isenção de análise ou de decisão, nomeadamente em virtude de:

a. Ter sido colaborador da sociedade ou de sociedade que com ela se encontre em relação de domínio ou de grupo nos últimos três anos;

b. Ter, nos últimos três anos, prestado serviços ou estabelecido relação comercial significativa com a sociedade ou com sociedade que com esta se encontre em relação de domínio ou de grupo, seja de forma direta ou enquanto sócio, administrador, gerente ou dirigente de pessoa coletiva;

c. Ser beneficiário de remuneração paga pela sociedade ou por sociedade que com ela se encontre em relação de domínio ou de grupo além da remuneração decorrente do exercício das funções de administrador;

d. Viver em união de facto ou ser cônjuge, parente ou afim na linha reta e até ao $3 .^{\circ}$ grau, inclusive, na linha colateral, de administradores ou de pessoas singulares titulares direta ou indiretamente de participação qualificada;

e. Exercer funções executivas em sociedades onde exercem igualmente funções de administração outros membros executivos do órgão de administração da sociedade;

f. Ser titular de participação qualificada ou representante de um acionista titular de participações qualificadas.

Como visto, a definição apresentada pela Comissão do Mercado de Valores Mobiliários é ligeiramente mais detalhada e possui uma redação um 
pouco mais precisa. De qualquer forma, a comparação de ambos com o caso brasileiro é pouco conclusiva, restando claro que são de bases similares, não havendo grandes inovações.

\subsubsection{Alemanha}

Por fim, em terras germânicas, o tema da governança corporativa é regulado, principalmente, pelo Deutscher Corporate Governance Kodex ${ }^{77}$, o Código Alemão de Governança Corporativa, ou, ainda, German Corporate Governance Code. Este código, criado em 2003, foi recentemente atualizado em 05 de maio de 2015, e, além de ter sua base legal prevista na própria lei alemã de sociedades anônimas, estabelece alguns conceitos e previsões obrigatórias a companhias atuantes no mercado de capitais alemães, ao passo que outras de suas previsões são apenas recomendáveis ${ }^{78}$. Nesse cenário, tais previsões são relativas ao Aufsichtsrat, órgão administrativo colegiado semelhante ao conselho de administração brasileiro, mas que a este não é idêntico. Todavia, para fins de tradução e compreensão no presente trabalho, é feito um paralelo entre ambos os institutos.

Neste cenário, o Código Alemão de Governança Corporativa estabelece obrigações de independência tanto para diretores, quanto para conselheiros, conforme abaixo:

4.1. A diretoria é responsável por administrar a companhia de forma independente, nos interesses da companhia, e, portanto, levando em consideração os interesses dos acionistas, funcionários e demais detentores de valores mobiliários emitidos pela companhia, objetivando a criação de valor da companhia.

\footnotetext{
77 Disponível em: http://www.dcgk.de//files/dcgk/usercontent/en/download/code/2015-0505 Corporate_Governance_Code_EN.pdf. Acessado em 25/09/2015.

78 Conforme previsto no site do próprio código alemão de governança, disponível em: http://www.dcgk.de/en/code.html. Acessado em 25/09/2015.
} 
5.4.2. O Conselho de Administração deverá ser composto por um número adequado de membros independentes. Nos termos desta recomendação, um membro do conselho de administração não poderá ser considerado independente caso ele/ela tenha relações pessoais de negócios com a companhia, com os seus órgãos administrativos, com um acionista controlador ou sociedade associada a este ultimo, que possam causar um substancial, e não meramente temporário, conflito de interesses. Não mais que dois membros da diretoria poderão ser membros do conselho de administração. Membros do conselho de administração não poderão exercer cargos de direção ou postos similares, ou ainda de consultoria, a competidores importantes da companhia.

\subsection{Ressalvas ao Conceito da BM\&FBOVESPA, críticas doutrinarias e questões atuais e correlatas}

Dentre críticos e defensores, é notável que são suscitadas diversas frentes de discussão acerca da existência da própria figura do conselheiro independente, bem como ao conceito atualmente existente e vigente.

Como visto acima, o conceito atualmente vigente e obrigatório no Brasil, qual seja, aquele da BM\&FBOVESPA para companhias negociando suas ações no Novo Mercado e no Nível 2, é até certo ponto condizente com os conceitos estrangeiros, já que nestes foi baseado, consideradas as particularidades do mercado acionário de cada país. Apesar da crítica pela falta de detalhes e pelo caráter vago de diversos termos utilizados no conceito da BM\&FBOVESPA, tais não são os apontamentos mais graves feitos pela doutrina especializada a tal conceito.

A discussão de maior polêmica e profundidade jurídica reside no conflito gerado, pela figura do conselheiro independente, dos dispositivos legais consubstanciados no artigo $154^{79}$ e nos parágrafos $8^{\circ}$ e $9^{\circ}$ do artigo

\footnotetext{
79 "Art. 154. O administrador deve exercer as atribuições que a lei e o estatuto lhe conferem para lograr os fins e no interesse da companhia, satisfeitas as exigências do bem público e da função social da empresa.
} 
$118^{80}$, ambos da Lei das S.A. Enquanto o primeiro concede ao membro do conselho de administração o dever classificado pela doutrina como dever de independência, já aludido no presente trabalho, ao prever que este deve exercer suas atribuições voltado para os fins de interesse da companhia, e não apenas do acionista que o elegeu, o segundo dispositivo legal estabelece que o voto do conselheiro em reunião do conselho de administração proferido contra acordo de acionistas não será computado.

O que ocorre na prática, com base nos parágrafos supramencionados do Art. 118 da Lei das S.A., é que, anteriormente à reunião do conselho de administração, acionistas possuidores do controle da companhia através de acordo de acionistas de controle, fazem as chamadas "reuniões prévias", a fim de discutirem as matérias a serem debatidas na reunião do conselho. A decisão de tais reuniões prévias passa, então, a ser vinculante ao conselheiro independente, que, caso vote de maneira contrária na reunião do órgão deliberativo, corre o risco de não ter seu voto computado, e mais, de ter outra pessoa representante do grupo de controle votando em seu lugar.

Neste sentido, a doutrina passou a se dividir em três correntes. ${ }^{81} \mathrm{~A}$ primeira, argumenta que o dever de independência se compatibiliza com a

$\S 1^{\circ} \mathrm{O}$ administrador eleito por grupo ou classe de acionistas tem, para com a companhia, os mesmos deveres que os demais, não podendo, ainda que para defesa do interesse dos que o elegeram, faltar a esses deveres."

80 “Art. 118. Os acordos de acionistas, sobre a compra e venda de suas ações, preferência para adquirilas, exercício do direito a voto, ou do poder de controle deverão ser observados pela companhia quando arquivados na sua sede.

§ 80 O presidente da assembleia ou do órgão colegiado de deliberação da companhia não computará o voto proferido com infração de acordo de acionistas devidamente arquivado.

$\S 90 \mathrm{O}$ não comparecimento à assembleia ou às reuniões dos órgãos de administração da companhia, bem como as abstenções de voto de qualquer parte de acordo de acionistas ou de membros do conselho de administração eleitos nos termos de acordo de acionistas, assegura à parte prejudicada o direito de votar com as ações pertencentes ao acionista ausente ou omisso e, no caso de membro do conselho de administração, pelo conselheiro eleito com os votos da parte prejudicada."

81 GORGA, Erica; GELMAN, Marina. O esvaziamento crescente do Conselho de Administração como efeito da vinculação de seu voto a acordos de acionistas no Brasil. $1^{\circ}$ colocado no Prêmio IBGC Itaú Academia e Imprensa. 2012. p. 8. 
vinculação de voto dos administradores, pois o acordo de controle atenderia ao interesse social. Para este grupo predominante, dentre do qual se destacam CARVALHOSA $^{82}$, EIZIRIK $^{83}$, ARAGÃO $^{84}$ e BULHÕES PEDREIRA ${ }^{85}$, interesse social é interesse da maioria, e, por ser o grupo de controle representativo da maioria dos acionistas, seu interesse se confunde com o interesse social. A segunda corrente doutrinaria afirma que, apesar da compatibilidade de ambos dispositivos legais, a interpretação sistemática da lei leva à conclusão de que o dever de independência seria inabalável, e que, portanto, os administradores que têm seu voto vinculado ao acordo de acionistas devem manter sua independência para contrariar esta obrigação sempre que entenderem que seu cumprimento não está de acordo com o interesse social. Por último, está a corrente doutrinaria que entende que a vinculação dos conselheiros a acordos de acionistas contrariam diretamente o seu dever de independência, restringindo a liberdade de ação que a eles é preconizada pela própria lei.

A lição de ARAGÃO é precisa para a compreensão desta questão insurgida:

Novidade relevante, e cujo efeito talvez não se tenha ainda apreendido, é a previsão específica de que os acordos de acionistas podem irradiar seus efeitos sobre outros órgãos de deliberação colegiada da companhia.

\footnotetext{
${ }^{82}$ CARVAlhosA, Modesto. Comentários à lei das sociedades anônimas. Vol. 3. $4^{a}$ edição. São Paulo: Saraiva. 2009. pp. 274-279.

83 EIZIRIK, Nelson. Acordo de Acionistas - arquivamento na sede social - vinculação dos administradores de sociedade controlada. Revista de Direito Mercantil, Industrial, Econômico e Financeiro, n. 129, pp. 45-53, janeiro-março 2003.

${ }^{84}$ ARAGÃO, Paulo Cézar. A disciplina do Acordo de Acionistas. In: LOBO, Jorge (coord.). Reforma da lei das sociedades anônimas: inovações e questões controversas da Lei n. 10.303/2001. Rio de Janeiro: Forense. 2002. pp. 374.

${ }^{85}$ BULHÕES PEDREIRA, José Luiz. Acordo de acionistas sobre controle de grupo de sociedades. Validade da estipulação de que os membros do conselho de administração de controladas devem votar em bloco segundo orientação definida pelo grupo controlador.Parecer In: Revista de Direito Bancário, de Mercado de Capitais e da Arbitragem, ano 5, no. 15, janeiro-março de 2002. São Paulo: Editora Revista dos Tribunais. 2002.
} 
Sustentam alguns, ainda que contra a limitada jurisprudência existente, o entendimento de que acordos de acionistas não podem vincular os membros do conselho de administração, e, mais ainda, os diretores da companhia, agindo colegiadamente.

O conceito estaria baseado no princípio, inscrito no $\S 1^{\circ}$ do art. 154 da Lei $n^{o}$ $6.404 / 76$, de que o conselheiro vota no interesse da companhia, sem vinculação com aqueles acionistas que o elegeram ou com obrigações contratuais por eles assumidas, o que levou alguns à conclusão de que os acordos de acionistas não vinculavam os conselheiros.

No entanto, a lei claramente afasta-se desta posição, estabelecendo no citado $\S 8^{\circ}$ que o presidente do conselho de administração (...) poderá também suprir o voto do conselheiro que não o manifeste conforme o acordo de acionistas.

A lei, desta forma, adotou a orientação de Waldirio Bulgarelli, no sentido de que, conforme aquele precedente jurisprudencial citado, pode o acordo de acionistas efetivamente vincular a manifestação dos conselheiros eleitos pelos acionistas que figuram no próprio acordo, gerando o que a jurisprudência definiu como 'efeito cascata, ${ }^{86}$

Por outro lado, de forma a ilustrar a segunda corrente doutrinária mencionada acima, é cabível a opinião de CEREZETTI, que afirma:

Em face da modificação da regra que disciplina os acordos de acionistas, e considerando o inabalável dever de independência e zelo pelo interesse da companhia, deve-se entender que o administrador não se vincula automaticamente à resolução de determinados acionistas, devendo tomá-la como recomendação a ser seguida se com ela concordar, sendo que a obediência cega à deliberação implica desrespeito aos seus deveres fiduciários. Entendimento diverso seria admitir entraves à livre determinação do agente fiduciário, que, como tal, deve ser, por natureza, dotado de absoluta autonomia. ${ }^{87}$

Neste sentido, ainda, fortes críticas a tal prática são feitas por GORGA e

GELMAN, ao afirmarem que:

Ainda que a previsão em acordos de acionistas de sujeição de determinados assuntos - que não sejam de competência do Conselho de Administração - à prévia deliberação do grupo de controle seja algo legítimo perante a lei tal como ela está redigida, o esvaziamento, ainda que parcial, do órgão deliberativo e tido como um dos principais mecanismos de boa governança corporativo é pernicioso para o desenvolvimento do mercado de capitais. ${ }^{88}$

\footnotetext{
${ }^{86}$ ARAGÃO, Paulo Cézar. Op. Cit. p. 375.

${ }^{87}$ CEREZETTI, Op. Cit. p. 592

${ }^{88}$ GORGA, Erica; GELMAN, Marina. Op. Cit. p. 14.
} 
As autoras continuam e concluem:

Os acordos de acionistas estão operando, de fato e de forma crescente, como um instrumento de anulação do dever de independência e comprometimento do pleno exercício das funções do Conselho de Administração. Neste contexto, o interesse do controlador representado no acordo de acionistas não pode ser presumido como de acordo com o interesse social da companhia.

Não se adentrará o debate do que é o interesse social. (...) Mas ambas as doutrinas dizem que o interesse social só é resguardado quando os atos societários atendem à lei, e como vimos, diversos acordos de acionistas analisados não atendem a lei, portanto, não podem atender o interesse social, não importando a teoria que se use para embasar o interesse social.

Não obstante sua posição a respeito da vinculação de conselheiros independentes ao bloco controlador por meio do acordo de acionistas de controle, CARVALHOSA faz a seguinte ressalva:

No direito societário brasileiro, por força do Art. 118 da Lei n. 6404/76, em sua redação dada pela Lei $n$. 10.303/2001, estabelece-se uma hegemonia absoluta dos controladores sobre o Conselho de Administração e a diretoria da sociedade. Essa hegemonia dos controladores sobre os administradores decorrente dos acordos de voto em bloco demonstra a falácia dos princípios de governança corporativa que os promotores da Lei n. 10.303/2001 propalaram como o motivo fundamental da alteração da lei societária. ${ }^{89}$

Aspecto relevante à discussão supra, acerca do vínculo dos conselheiros aos acordos de acionistas de controle, é sobre a delegação de poderes entre órgãos da companhia. Há enorme discussão doutrinária acerca da viabilidade do acordo de acionistas, das decisões tomadas pelos acionistas signatários de tais acordos em "reuniões prévias", ou de decisões dos acionistas de maneira geral, versarem sobre matérias de competência do conselho de administração. Sobre o tema, EIZIRIK aponta:

${ }^{89}$ CARVALHOSA, Modesto. Comentários à lei das sociedades anônimas. V.2. São Paulo: Editora Saraiva. p. 15. 
O estatuto social, como lei interna da companhia, pode criar outras hipóteses de deliberação privativa da assembleia geral, conforme o interesse da companhia. (...) Caso o estatuto social proceda dessa forma, atribuindo a determinado órgão social a competência sobre uma matéria específica, esta reserva de competência deve ser necessariamente observada pelos acionistas, uma vez que as normas estatutárias possuem força de direito inerente ao agrupamento, isto é, têm natureza obrigatória, devendo ser permanentemente respeitadas por todos os acionistas. ${ }^{90}$

Neste sentido, BULHÕES PEDREIRA e LAMY FILHO ensinam que "se existente o conselho, só ele pode eleger os diretores, sem embargo do poder que detém a assembleia de instrui-lo a os substituir. "(grifo nosso) $)^{91}$

Já DA SILVA, em contrapartida, faz uma análise moderadamente mais cautelosa desta questão, ao afirmar que:

Entendemos que somente os incisos VI, VII e VIII [do art. 142] poderiam ser objeto de deliberação em assembleia ou delegados a outro órgão no estatuto social da companhia. Os demais incisos representam, portanto, competência privativa do conselho de administração, de forma que o estatuto social somente poderia especificar mais informações sobre eles, mas não contrariá-los, tampouco transferilos a outro órgão. ${ }^{92}$

Uma omissão falha no conceito da BM\&FBOVESPA, muito bem apontada por DA SILVA e DE CARVALHO ${ }^{93}$, reside no fato de que a independência do conselheiro independente ser constantemente ameaçada pela destituição do seu cargo que pode ser feita a qualquer tempo pelo acionista que o elegeu. VERÇOSA é outro que faz esta ressalva, nos seguintes termos: “Aliás, falar em 'conselheiros independentes' é uma inverdade, pois qualquer deles sempre poderá ser demitido pelo controlador sem qualquer justificativa." 94

\footnotetext{
${ }^{90}$ EIZIRIK, Nelson. A Lei das S.A. comentada. Vol. II.São Paulo: Quartier Latin. 2011. p. 22

${ }^{91}$ BULHÕES PEDREIRA, José Luiz; LAMY FILHO, Alfredo. Op. Cit. p. 882

${ }^{92}$ DA SILVA, Thiago José. Limites à vinculação de administradores. Dissertação de Mestrado apresentada na Faculdade de Direito da Universidade de São Paulo. 2014. p. 88.

93 DA SILVA, Thiago José; DE CAMARGO, André Antunes de Soares. Op. Cit. p. 76

${ }^{94}$ VERÇOSA, Haroldo Malheiros Duclerc.. Op. Cit. p. 434.
} 
Ainda com relação a esta lacuna conceitual, GELMAN faz a seguinte observação pertinente:

De fato, se o ocupante do cargo tiver, em determinada situação, que optar entre defender os interesses de quem tem poder para demiti-lo ou destitui-lo, e assim manter seu emprego, ainda que eventualmente em detrimento de uma atuação independente, ou agir de forma independente, de acordo com seu entendimento pessoal, mas contrariamente aos interesses do grupo controlador e, assim, desagradar quem tem o poder de lhe tirar seu emprego, provavelmente ele optará por manter seu emprego, perdendo a possibilidade de agir meramente de acordo com sua convicção. ${ }^{95}$

Como possível solução deste impasse, DA SILVA e DE CAMARGO defendem, como proteção a destituições ad nutum dos conselheiros independentes, o impedimento de o acionista controlador realizar tais destituições em casos específicos, nos quais tal atitude caberia aos demais acionistas em conjunto. ${ }^{96}$ GELMAN se posiciona de maneira parecida, inclusive sugerindo a inclusão de um novo item no conceito da BM\&FBOVESPA, que teria sua redação nos seguintes termos:

4.3.4 $O(s)$ Conselheiro(s) Independente(s) eleitos pelo Acionista Controlador não poderá(ão) ser destituído(s) durante o exercício do mandato para o qual tiver(em) sido eleito(s), exceto por falta grave. $O$ ato de destituição do Conselheiro Independente deve conter justificativa expressa do motivo de sua destituição. ${ }^{97}$

Em contrapartida às críticas feitas aos critérios vagos e dúbios existentes, PRADO e VILELA, por sua vez, criticam as definições do IBGC e da BM\&FBOVESPA por serem justamente técnicas e específicas em demasia, como observado:

(...) A independência deve ser compreendida muito mais como um reflexo das atitudes do conselheiro do que propriamente com conceitos excludentes, como faz a $B M \& F B O V E S P A$ e o IBGC. (...) independente é o conselheiro que atua

\footnotetext{
${ }^{95}$ GELMAN, Marina Oehling. Op Cit. p. 123.

${ }^{96}$ DA SILVA, Thiago José; DE CAMARGO, André Antunes de Soares. Op. Cit. P. 77.

${ }^{97}$ GELMAN, Marina Oehling. Op. cit. p. 133.
} 
racionalmente e de forma diligente com base nas informações que possui ou que possa produzir, levando em conta os objetivos de todos os acionistas ou cotistas e os limites que afetam os interesses da empresa como um todo e dos seus demais stakeholders. (...) Deve então ser considerado independente o profissional que, por exemplo, não se intimida ao votar em desacordo com o interesse do controlador ou do acionista que o indicou para o cargo, a fim de sustentar uma posição alinhada aos valores que lhe atribuem a confiança e a competência necessárias à função, $e$ não aquele sujeito que meramente se enquadra nas determinações legais ou regulamentares para ser considerado um conselheiro independente. ${ }^{98}$

\title{
GOUVÊA VIEIRA é outro que faz uma importante ressalva à atuação
}

\section{do conselheiro independente, nos seguintes termos:}

\begin{abstract}
Mas, para que possamos realmente demandar um patamar mais elevado de comprometimento por parte do conselheiro independente(...) há uma contrapartida (...) a tão desejável, saudável e necessária transparência. (...) A carência de informações, ao contrário, só o conduzirá à constrangedora contingência de limitarse a atuar como um fiscal, envolvido em perverso jogo de 'esconde-esconde'. (...) Muitos diretores agem como se devessem satisfações apenas aos conselheiros proprietários, representantes dos controladores. Esse comportamento gera o isolamento do conselheiro independente. ${ }^{99}$
\end{abstract}

Há, ainda, quem defenda que os conselheiros da companhia não devem de forma alguma ser vistos como independentes. ARAGÃO ${ }^{100}$, ao tratar da eleição dos conselheiros pelos acionistas, faz a seguinte advertência:

Sua indicação, desde o início, nada mais representa do que a nomeação de um preposto para representar o acionista na reunião do Conselho de Administração, e não a indicação de um terceiro verdadeiramente independente, que irá representar, de forma não particular, o interesse de todos os acionistas.

98 PRADO, Roberta Nioac; VILELA, Renato. Apontamentos sobre a evolução do Conselho de Administração no Brasil a partir dos anos 1980. In: FONTES FILHO, Joaquim Rubens; CAMARA LEAL (Coord.). Governança Corporativa: discussões sobre os conselhos em empresas no Brasil. São Paulo: Saint Paul, 2012. p. 263

99 GOUVÊA VIEIRA, Antonio Alberto. A transparência $e$ o engajamento do conselheiro. Considerações sobre os conselhos de administração das empresas. In: (FOTES FILHO, Joaquim Rubens; CÂMARA LEAL (coord.). Governança Corporativa: discussões sobre os conselhos em empresas no Brasil. São Paulo: Saint Paul. 2012. P. 298.

${ }^{100}$ ARAGÃO, Paulo Cezar. Op. Cit. p. 376. 
O autor supramencionado não está solitário em sua posição, sendo acompanhado por doutrinadores brasileiros e estrangeiros na sua crítica à existência dos conselheiros independentes. Muitas dessas defendem que os conselheiros independentes seriam economicamente prejudiciais ao desempenho econômico das companhias, mas não entraremos em maiores detalhes sobre esta discussão acerca do impacto financeiro dos independentes por não ser objeto do presente trabalho. De qualquer forma, também não são raras as matérias publicadas pela imprensa se posicionando contra a existência dos conselheiros independentes. ${ }^{101}$

Na contramão desta posição, lastreado no crédito que os conselheiros independentes angariaram com o público e mercado geral, temos atualmente, inclusive, discussões sobre a inclusão de previsões de obrigatoriedade de membros independentes em conselhos de administração de companhias de economia mista, nas quais o Estado figura necessariamente como acionista majoritário e controlador. ${ }^{102}$ Para estes casos, seria razoável a criação de um novo conceito, diferente dos atualmente existentes no país, para refletir as diferentes características de uma sociedade de economia mista, quando em comparação a uma sociedade anônima comum. Neste sentido, poderia, inclusive, constar o veto a membros filiados ao partido associado à presidência da república. Hipoteticamente falando, acredita-se que, possivelmente, desta forma, poderiam ter sido evitados escândalos recentes na história do país, envolvendo transações bilionárias e fraudulentas, utilizadas para o desvio ilegal de verbas a campanhas políticas e corrupção, que praticamente quebraram uma das maiores companhias de economia mista do país, e que foram aprovadas no conselho da companhia por membros filiados ao partido

\footnotetext{
101 TANOUE, Luciana. O conselho que queremos. Eficácia dos boards com grande parcela de independentes é questionada no Brasil e no Mundo. Revista Capital Aberto, edição no. 118, junho 2013. pp.29-30.

102 Disponível em: http://exame.abril.com.br/negocios/noticias/bovespa-quer-20-de-conselheirosindependentes-em-estatais
} 
político que se beneficiaria de tal esquema. Verifica-se que, em tal conselho, membros eleitos por acionistas minoritários costumam ter uma atuação mais consciente e isenta de vínculos políticos, como verificado recentemente. ${ }^{103}$ Caso existissem conselheiros independentes no conselho de administração de sociedades de economia mista, seria maior o controle, e menor a conivência, com esquemas de corrupção e desvio de verbas públicas que, lamentavelmente, estampam quase que diariamente as principais manchetes dos jornais do país.

De qualquer forma, são feitas diversas sugestões de ajustes à atual definição da BM\&FBOVESPA para o conselheiro independente, com vistas a uma maior efetividade desta. Além da proposta acima referida relativa à (não-) destituição dos conselheiros, podemos citar também outra ideia de DA SILVA e DE CAMARGO, os quais propõem a exigência de perfil profissional mínimo para o conselheiro independente, tal qual formação superior, cursos específicos ou tempo mínimo de experiência como administrador ${ }^{104}$. Além disso, tais autores também preconizam pelo estabelecimento de um tempo máximo de permanência na função, tendo em vista que um longo mandato poderia comprometer a independência de um dado conselheiro. GELMAN ${ }^{105}$ também se posiciona sobre o assunto, ao recomendar que, para que o conselheiro possa exercer suas funções de forma plenamente independente, deve ser inserida no conceito da BM\&FBOVESPA o veto ao vínculo deste ao acordo de acionista arquivado na sede da Companhia, cuja discussão foi acima abordada.

Assim sendo, verifica-se a pluralidade de sugestões ao atual conceito, bem como a gama de críticas diretas feitas. Considerando-se que a figura do conselheiro independente já é uma realidade no país, e defendida pela maioria

\footnotetext{
103 Disponível em: http://oglobo.globo.com/economia/conselheiros-independentes-da-petrobrasquestionam-metodologia-usada-para-baixa-contabil-15999568

${ }^{104}$ DA SILVA, Thiago José; DE CAMARGO, André Antunes de Soares. Op. Cit. P. 77.

${ }^{105}$ Gelman. Marina Oehling. Op. Cit. p. 152-153.
} 
da doutrina especializada, é mister que tais melhorias sugeridas em sede de doutrina sejam, ao menos, imparcialmente analisadas, com vistas à evolução de um conceito que, de forma unânime, ainda é considerado inadequado. 


\section{CONCLUSÃO}

Como se pôde ver ao longo desta monografia, há pouco espaço para unanimidade quando o tema em debate é o conselheiro independente. Tanto a própria existência deste tipo de conselheiro, quanto principalmente o seu conceito e os critérios utilizados para a verificação se determinado conselheiro pode, de fato, ser considerado como independente, são fruto de diversas críticas por parte da doutrina, por empresas e por pessoas e entidades atuantes no mercado de capitais.

Não há dúvidas, por outro lado, que a governança interna, de maneira geral, é extremamente bem vista por investidores que buscam o mercado de ações, os quais consideram as práticas associadas à boa governança corporativa essenciais a um bom e seguro investimento. Adicionalmente, restou clara a compatibilidade da figura do conselheiro independente com mercados de concentração e de dispersão acionária, sendo, em cada um desses, diferente o escopo de atuação do conselheiro independente quanto aos conflitos de agência. Ainda, viu-se que a eleição de membros independentes para o conselho de administração de companhias cujas ações são negociadas em bolsa constitui um dos principais instrumentos de boa governança interna, sendo, portanto, adotado ao redor do globo.

Não obstante, não há qualquer vantagem para a companhia em eleger conselheiros que, na prática, poucos benefícios trazem à companhia. Além disso, também não se pode admitir que as normas aplicáveis a conselheiros independentes sejam de tal forma redigidas a abrir brechas para a eleição de profissionais que, na prática, de independentes não têm nada. Mais nefasta, ainda, é a verificação de que, inapropriada com as características do mercado de capitais brasileiro, bem como com a legislação societária vigente, o 
conselheiro independente não tome decisões voltadas, em primeiro lugar, aos interesses da companhia, que deve ser o norte de qualquer decisão tomada por qualquer conselheiro.

Como se viu, portanto, dentre as parcas opiniões uníssonas sobre o tema, seja entre defensores ou opositores à existência de conselheiros independentes em companhias listadas, está o entendimento de que o conceito atualmente vigente no país para a eleição de conselheiros independentes apresenta falhas, imperfeições, não cumprindo com o objetivo buscado quando de sua criação. É necessário um conceito preciso, que seja condizente com a realidade de dispersão acionária nacional, e que funcione de maneira harmoniosa com a Lei das S.A. Caso contrário, corre-se o risco de que importantes instrumentos de governança interna sofram pressões externas e percam aplicabilidade, o que seria muito perigoso para um mercado de capitais que já não possui grande volume de investimentos, principalmente externos, e ainda é visto como especulativo e inseguro por grande parte das pessoas. Logo, deve ser permitido que o conselheiro independente, acima de qualquer coisa, possa exercer o seu cargo de forma estável e realmente independente, para que possam ser aproveitados os seus benefícios pela companhia, bem como pelo mercado como um todo. 


\section{BIBLIOGRAFIA}

\section{Livros e Artigos de Periódicos:}

ADAMEK, Marcelo Vieira von. Responsabilidade dos Administradores de S.A. e as Ações Correlatas. São Paulo: Editora Saraiva, 2009.

ARAGÃO, Paulo Cezar. A disciplina do acordo de acionistas na reforma da lei das sociedades por ações: Lei $n^{\circ}$ 10.303/2001. In: LOBO, Jorge (org.) Reforma da lei das sociedades anônimas: inovações e questões controvertidas da Lei 10.303, de 31/10/2001. Rio de Janeiro: Forense. 2002. $1^{a}$ edição.

BERLE, Adolf e MEANS, Gardiner. Modern Corporation and Private Property. Londres: Transaction Pub. 10 ad. 2010.

BULHÕES PEDREIRA, José Luiz; LAMY FILHO, Alfredo, Direito das Companhias, volumes I e II. Rio de Janeiro: Forense. 2009. $1^{\text {a }}$ edição.

CARVALHAL, André da Silva; LEAL, Ricardo P.C. Corporate Governance, Market Valuation and Dividend Policy in Brazil. In: Coppead Working Papers No. 390. 2003.

CARVALHO, Antonio Gledson de. Ascensão e Declínio do Mercado de Capitais no Brasil: A Experiência dos Anos 90. São Paulo. 2000. Disponível em http://ssrn.com/abstract $=1010732$

CEREZETTI, Sheila Christina Neder. Administradores Independentes e Independência dos Administradores (Regras Societárias Fundamentais ao Estímulo do Mercado de Capitais Brasileiro). In: ADAMEK, Marcelo Vieira 
von (Coord.) Temas de Direito Societário e Empresarial Contemporâneos. São Paulo: Editora Malheiros. 2011. $1^{\mathrm{a}}$ edição.

CLARKE, Donald C. Three Concepts of the Independent Director. Delaware Journal of Corporate Law, Vol. 32, $\mathrm{N}^{\mathrm{0}} 1.2007$.

Código de Melhores Práticas de Governança Corporativa. Instituto Brasileiro de Governança Corporativa.. 4a ed. São Paulo: IBGC, 2009.

DA SILVA, Thiago José. Limites à vinculação de administradores. Dissertação de Mestrado apresentada na Faculdade de Direito da Universidade de São Paulo. 2014.

DA SILVA, Thiago José; DE CAMARGO, André Antunes Soares. Conselheiros Independentes - Status e Proposições. Revista de Direito das Sociedades e Dos Valores Mobiliários, n. 1. São Paulo.

DEMOTT, Deborah. Guests at the Table: Independent Directors in FamilyInfluenced Public Companies. Duke Law School Legal Studies Paper No. 165. 2007.

EIZIRIK, Nelson. A Lei das S.A. comentada. Vol. II. São Paulo: Quartier Latin. 2011.

EIZIRIK, Nelson; GAAL, Adriana B; PARENTE, Flávia; HENRIQUES, Marcus de Freitas. Mercado de Capitais. Regime Jurídico. Rio de Janeiro: Renovar. 2011. $3^{\text {a }}$ edição. 
FILHO, Joaquim Rubens; CAMARA LEAL (Coord.). Governança Corporativa: discussões sobre os conselhos em empresas no Brasil. São Paulo: Saint Paul. 2012.

GARCIA, Letícia Simonetti. O controle nas companhias abertas brasileiras de capital pulverizado. São Paulo. Tese (Doutorado em Direito). PUC-SP. 2008.

GELMAN, Marina Oehling. O Conceito de Conselheiro Independente vigente na Regulamentação dos Niveis Diferenciados de Governança Corporativa da BM\&FBOVESPA. 2012. Tese (Mestrado em Direito) - Fundação Getúlio Vargas (FGV-SP).

GORDON, Jeffrey N. The rise of independent directors in the United States, 1950-2005: of shareholder value and 'stock market prices. Stanford Law Review, vol. 59. 2007.

GORGA, Érica. Changing the paradigm of stock ownership from concentrated towards dispersed ownership? Evidences from Brazil and consequences for emerging countries. In: Northwestern Journal of International Law \& Business,

GOUVÊA VIEIRA, Antonio Alberto. A transparência e o engajamento do conselheiro. Considerações sobre os conselhos de administração das empresas. In: FOTES FILHO, Joaquim Rubens; CÂMARA LEAL (coord.). Governança Corporativa: discussões sobre os conselhos em empresas no Brasil. São Paulo: Saint Paul. 2012. P. 298.

HANSMANN, Henry; KRAAKMAN, Reinier. The end of history for corporate law. Georgetown Law Journal, Washington. n. 89. 2001. 
LOBO, Jorge. Princípios de governança corporativa. Revista de Direito Mercantil, Industrial, Econômico e Financeiro, no. 142. São Paulo: Malheiros. 2006.

MARTINS NETO, Carlos. Dispersão acionária, tomada hostil de controle e poison pills:Breves reflexões. Revista Semestral de Direito Empresarial, $\mathrm{n}^{\circ} 5$. 2009.

Mercado de Valores Mobiliários Brasileiro. Comissão de Valores Mobiliários. Rio de Janeiro, 2014.2 Disponível em: http://www.cvm.gov.br/menu/investidor/publicacoes/livros.html.

MORAES, Luiza Rangel. A pulverização do controle de companhias abertas. Revista de Direito Bancário e do Mercado de Capitais. São Paulo: Revista dos Tribunais, $\mathrm{n}^{\circ} 32$, abril-junho/2006.

MUNHOZ, Eduardo Secchi. Desafios do Direito Societário Brasileiro na Disciplina da Companhia Aberta: Avaliação dos sistemas de controle diluido e concentrado. In: DE CASTRO, Rodrigo R. M.; ARAGÃO, Leandro Santos (Coord.) Direito Societário - Desafios Atuais.. São Paulo: Quartier Latin. 2009.

NOVAES FRANÇA, Erasmo Valadão Azevedo e. Dever de informar dos administradores de companhias abertas. Inexistência de submissão ao acionista controlador. São Paulo: Malheiros Editores. 2009.

PARENTE, Norma. Principais Inovações introduzidas pela Lei $n^{\circ} 10.303$, de 31 de outubro de 2011, à Lei de Sociedades por Ações. In: LOBO, Jorge 
(coord.). Reforma da lei das sociedades anônimas: inovações e questões controversas da Lei $n$. 10.303/2001. Rio de Janeiro: Forense. 2002

PRADO, Roberta Nioac; VILELA, Renato. Apontamentos sobre a evolução do Conselho de Administração no Brasil a partir dos anos 1980. In: FONTES FILHO, Joaquim Rubens; CAMARA LEAL (Coord.). Governança Corporativa: discussões sobre os conselhos em empresas no Brasil. São Paulo: Saint Paul, 2012.

SAlOMÃo FILHO, Calixto. O Novo Direito Societário. $4^{\text {a }}$ ed. São Paulo: Malheiros. 2011.

SILVEIRA, Alexandre di Miceli. Governança Corporativa no Brasil e no Mundo - teoria e prática. Rio de Janeiro: Elsevier, 2010.

SILVEIRA, Alexandre di Miceli, Governança Corporativa, Desempenho e Valor da Empresa no Brasil. São Paulo. 2002. Tese (Mestrado em Economia). Faculdade de Economia, Administração e Contabilidade da Universidade de São Paulo (USP).

VALADARES, Silvia Mourthe; LEAL, Ricardo P.C. Ownership and Control Structure of Brazilian Companies

VERÇOSA, Haroldo Malheiros Duclerc. Curso de direito comercial. v. 3. $2 a$ ed. São Paulo: Malheiros. 2011.

\section{Sites da Internet:}

http://uscode.house.gov/download/pls/15C98.txt. 
http://www.sec.gov/about/laws/wallstreetreform-cpa.pdf

http://www.bmfbovespa.com.br/pt-br/servicos/solucoes-paraempresas/segmentos-de-listagem/o-que-sao-segmentos-delistagem.aspx?idioma=pt-br.

http://ssrn.com/abstract $=1010732$

http://ssrn.com/abstract $=928100$

http://ssrn.com/abstract $=975111$

http://ssrn.com/abstract $=213409$

http://ssrn.com/abstract $=1010732$

http://ssrn.com/abstract $=477302$

http://papers.ssrn.com/sol3/papers.cfm?abstract_id=1121037

http://www.dominiopublico.gov.br/download/teste/arqs/cp062700.pdf

http://papers.ssrn.com/sol3/papers.cfm?abstract $\mathrm{id}=1121037$

http://www.ibgc.org.br/userfiles/files/Codigo_Final_4a_Edicao.pdf.

http://www.cvm.gov.br/port/publ/cartilha.doc 
http://www.cvm.gov.br/export/sites/cvm/legislacao/pare/anexos/pare035.pdf.

http://www.bmfbovespa.com.br/Pdf/RegulamentoNMercado.pdf

http://www.bmfbovespa.com.br/Pdf/Folder_Nivel2.pdf

https://www.calpers.ca.gov/docs/forms-publications/global-principlescorporate-governance.pdf.

http://nysemanual.nyse.com/LCM/Sections

http://www.ecgi.org/codes/documents/provisional_cgcode_csrc.pdf

http://www.cgov.pt/images/stories/ficheiros/codigo_de_governo_das_sociedad es_do_ipcg.pdf

http://www.cgov.pt/images/stories/ficheiros/4. novo cd. gov. soc. cmvm.pdf

http://www.dcgk.de//files/dcgk/usercontent/en/download/code/2015-0505_Corporate_Governance_Code_EN.pdf.

http://www.dcgk.de/en/code.html

http://exame.abril.com.br/negocios/noticias/bovespa-quer-20-de-conselheirosindependentes-em-estatais

http://oglobo.globo.com/economia/conselheiros-independentes-da-petrobrasquestionam-metodologia-usada-para-baixa-contabil-15999568 


\section{Anexo I - Detalhes das exigências de cada segmento de listagem da BMF\&BOVESPA.}

\begin{tabular}{|c|c|c|c|c|c|}
\hline & NOVO MERCADO & NIVEL 2 & NIVEL 1 & BOVESPA MAIS & TRADICIONAL \\
\hline $\begin{array}{l}\text { Caractorístlcas das } \\
\text { Açöos Emitidas }\end{array}$ & $\begin{array}{l}\text { Permite a existência } \\
\text { somente de açס̄es ON }\end{array}$ & $\begin{array}{l}\text { Permite a existência de } \\
\text { açס̄es ON } \theta \text { PN (com } \\
\text { direitos adicionais) }\end{array}$ & $\begin{array}{c}\text { Permite a existência de } \\
\text { açס̄es ON } \theta \text { PN } \\
\text { (conforme legislação) }\end{array}$ & $\begin{array}{c}\text { Somente açס̄es ON } \\
\text { podem ser negociadas } \\
\theta \text { emitidas, mas é } \\
\text { permitida a existência } \\
\text { de PN }\end{array}$ & 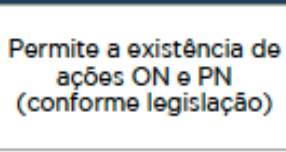 \\
\hline $\begin{array}{l}\text { Percentual Mínlmo de } \\
\text { Açōes om Clrculaçäo } \\
\text { (free float) }\end{array}$ & \multicolumn{3}{|c|}{ No minimo $25 \%$ de free float } & $\begin{array}{l}25 \% \text { de free float até o } \\
7^{2} \text { ano de listagem, ou } \\
\text { condiçōes minimas de } \\
\text { liquidez }\end{array}$ & Nāo há regra \\
\hline $\begin{array}{l}\text { Dlstribulę̧̋es públleas } \\
\text { de ạ̧రెes }\end{array}$ & \multicolumn{3}{|c|}{ Esforços de dispersão acionária } & \multicolumn{2}{|c|}{ Não há regra } \\
\hline $\begin{array}{l}\text { Vedação a dlsposlç̧̄es } \\
\text { estatutárlas (a partir de } \\
10 / 05 / 2011 \text { ) }\end{array}$ & \multicolumn{2}{|c|}{$\begin{array}{l}\text { Limitação de voto inferior a } 5 \% \text { do capital, } \\
\text { quorum qualificado } \theta \text { "cláusulas pétreas" }\end{array}$} & \multicolumn{3}{|c|}{ Não há regra } \\
\hline $\begin{array}{l}\text { Composlçào do } \\
\text { Consolho do } \\
\text { Adminlstraçăo }\end{array}$ & \multicolumn{2}{|c|}{$\begin{array}{c}\text { Minimo de } 5 \text { membros, dos quais pelo menos } \\
20 \% \text { devem ser independentes com mandato } \\
\text { unificado de até } 2 \text { anos }\end{array}$} & \multicolumn{3}{|c|}{ Minimo de 3 membros (conforme legislação) } \\
\hline $\begin{array}{l}\text { Vedaçĩo à acumulaçåo } \\
\text { de cargos (a partir do } \\
10 / 05 / 2011)\end{array}$ & \multicolumn{3}{|c|}{$\begin{array}{l}\text { Presidente do conselho e diretor presidente ou principal executivo pela } \\
\text { mesma pessoa (carência de } 3 \text { anos a partir da adesão) }\end{array}$} & \multicolumn{2}{|c|}{ Não há regra } \\
\hline $\begin{array}{l}\text { Obrigaçẩo do Conselho } \\
\text { de Adminlstraçđ̄o (a } \\
\text { partir do 10/05/2011) }\end{array}$ & \multicolumn{2}{|c|}{$\begin{array}{c}\text { Manifestaçāo sobre qualquer oferta pública de } \\
\text { aquisição de açōes da companhia }\end{array}$} & \multicolumn{3}{|c|}{ Nāo hả regra } \\
\hline $\begin{array}{l}\text { Demonstrạ̧öes } \\
\text { Flnancelras }\end{array}$ & \multicolumn{2}{|c|}{ Traduzidas para o inglø̂s } & \multicolumn{3}{|c|}{ Conforme legislação } \\
\hline $\begin{array}{l}\text { Reunläo públlea anual } \\
\text { calondárlo do eventos } \\
\text { corporatlvos }\end{array}$ & \multicolumn{3}{|c|}{ Obrigatório } & \multicolumn{2}{|c|}{ Facultativo } \\
\hline $\begin{array}{l}\text { Dlvulgaçåo adlelonal } \\
\text { de Informaçōes (a } \\
\text { partir do } 10 / 05 / 2011)\end{array}$ & \multicolumn{3}{|c|}{ Política de negociação de valores mobiliários $\theta$ código de conduta } & \multicolumn{2}{|c|}{ Nāo há regra } \\
\hline \multirow{2}{*}{$\begin{array}{l}\text { Concessäo de Tag } \\
\text { Along }\end{array}$} & \multirow{2}{*}{$100 \%$ para açōes ON } & $\begin{array}{l}\text { 100\% para açóes ON } \theta \\
\text { PN }\end{array}$ & \multirow{2}{*}{$\begin{array}{l}80 \% \text { para açōes ON } \\
\text { (conforme legislação) }\end{array}$} & \multirow{2}{*}{$100 \%$ para açס̄es ON } & \multirow{2}{*}{$\begin{array}{l}\text { 80\% para açōes ON } \\
\text { (conforme legislação) }\end{array}$} \\
\hline & & $\begin{array}{c}100 \% \text { para açס̄es ON } \theta \\
80 \% \text { para } \mathrm{PN} \text { (até } \\
09 / 05 / 2011)\end{array}$ & & & \\
\hline 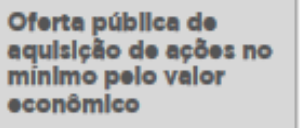 & \multicolumn{2}{|c|}{$\begin{array}{l}\text { Obrigatoriedade em caso de fechamento de } \\
\text { capital ou saida do segmento }\end{array}$} & Conforme legislação & $\begin{array}{l}\text { Obrigatoriedade em } \\
\text { caso de fechamento de } \\
\text { capital ou saida do } \\
\text { segmento }\end{array}$ & Conforme legislação \\
\hline $\begin{array}{l}\text { Adosảo à Câmara de } \\
\text { Arbltragem do } \\
\text { Mercado }\end{array}$ & \multicolumn{2}{|c|}{ Obrigatório } & Facultativo & Obrigatório & Facultativo \\
\hline
\end{tabular}

